Petroleum Geology and

Resources of

Southeastern Mexico,

Northern Guatemala, and

Belize

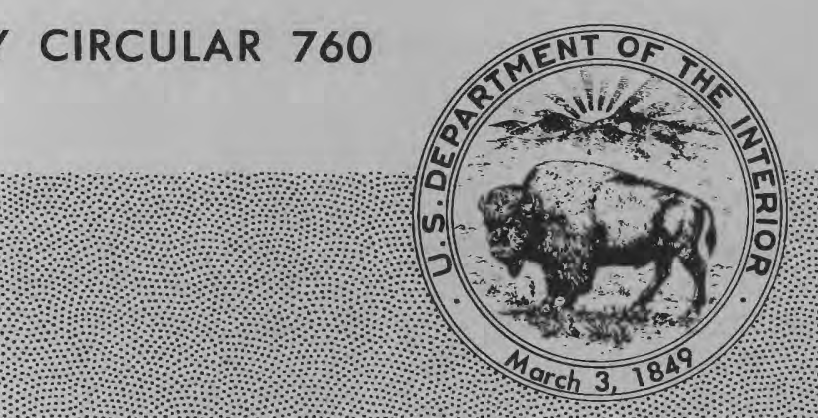

GEOLOGICAL SURVEY CIRCULAR 760 


\section{Petroleum Geology and}

Resources of

Southeastern Mexico,

Northern Guatemala, and

Belize

By James A. Peterson

GEOLOGICAL SURVEY CIRCULAR 760

Major reserves of oil occur in Cretaceous

and Paleocene microfractured dolomite

reservoirs on salt structures in the

Reforma and offshore Campeche areas of

southeastern Mexico 


\section{United States Department of the Interior \\ WILLIAM P. CLARK, Secretary}

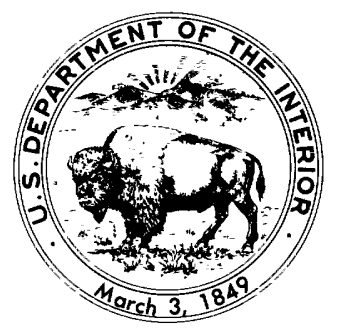

\section{Geological Survey}

Dallas L. Peck, Director

\section{Library of Congress Cataloging in Publication Data}

\section{Peterson, James A.}

Petroleum geology and resources of southeastern Mexico, northern Guatemala, and Belize.

(Geological Survey circular ; 760)

Bibliography: p.

Supt. of Docs. no.: I 19.4/2:760

1. Petroleum-Mexico. 2. Petroleum-Guatemala. 3. Petroleum-Belize. I. Title. II. Series.

QE75.C5 no.

$760557.3 \mathrm{~s}$

$\left[553.2^{\prime} 82^{\prime} 0972\right] \quad 83-600170$

[TN873.M6] 


\section{ASSESSMENT OF RECOVERABLE ENERGY RESOURCES}

The World Energy Resources Program of the U.S. Geological Survey (USGS) intends to develop reliable and credible estimates of undiscovered recoverable petroleum resources throughout the world. Initial program efforts have focused on the major producing areas of the world to gain a broad geological understanding of the characteristics of petroleum occurrence for purposes of resource assessment, as well as for analysis of production potential. Investigations of production potential are carried out in cooperation with other U.S. Government agencies; specifically, the studies of the main free world exporting nations, of which this study is a part, are carried out in cooperation with the Foreign Energy Supply Assessment Program of the Department of Energy. The estimates represent the views of a U.S. Geological Survey study team and should not be regarded as an official position of the U.S. Government.

The program seeks to investigate resource potential at the basin level, primarily through analogy with other petroleum regions, and does not necessarily require, therefore, current exploration information that is commonly held proprietary. In conducting the geological investigations, we intend to build a support base of publicly available data and regional geologic synthesis against which to measure the progress of exploration and thereby validate the assessment. Most of these investigations will lead directly to quantitative resource assessments; resource assessment, like exploration, to be effective, must be an ongoing process taking advantage of changing ideas and data availability - the results produced being progress reports reflecting on a state of knowledge at a point in time. Because this program is coordinated with the USGS domestic assessment program and both utilize similar techniques for assessment, the user can be assured of a thread of consistency permitting comparisons between the various petroleum basins of the world, including the United States, that have been assessed in the overall USGS program.

In addition to resource estimates, the program provides a regional base of understanding for in-country exploration analysis and for analysis of media reports regarding the exploratory success or failure of ventures in studied areas.

Other U.S. Geological Survey publications relating to the assessment of undiscovered conventionally recoverable petroleum resources include the following:

Open-File Report 81-0986-“Assessment of conventionally recoverable petroleum resources of Persian Gulf basin and Zagros fold belt (Arabian-Iranian basin)"

Open-File Report 81-1027- “Assessment of conventionally recoverable petroleum resources, Volga-Urals basin, U.S.S.R."

Open-File Report 81-1142-“"Assessment of conventionally recoverable petroleum resources of Indonesia"

Open-File Report 81-1143_-“Assessment of conventionally recoverable petroleum resources of northeastern Mexico"

Open-File Report 81-1144 - "Assessment of conventionally recoverable petroleum resources of southeastern Mexico, northern Guatemala, and Belize"

Open-File Report 81-1145- "Assessment of conventionally recoverable petroleum resources of Trinidad" Open-File Report 81-1146-“Assessment of conventionally recoverable petroleum resources of Venezuela"

Open-File Report 81-1147-“"Assessment of conventionally recoverable petroleum resources of the West Siberian basin and Kara Sea basin, U.S.S.R."

Open-File Report 82-0296-“"Assessment of undiscovered conventionally recoverable petroleum resources of the Middle Caspian basin, U.S.S.R."

These reports are available from the Open File Services Section, Branch of Distribution, USGS, Box 25425, Federal Center, Denver, CO 80225. 


\section{CONTENTS}

Page

Abstract _. . . . . . . . . . . . . . . . . 1

Introduction ........................ 1

Geography _..................... 1

Sources of data $\ldots \ldots \ldots \ldots \ldots 2$

Regional geology $\ldots \ldots \ldots \ldots \ldots \ldots$

Introduction _.................. 2

Stratigraphy _. . . . . . . . . . . . . . . 4

Paleozoic . . . . . . . . . . . . . . 8

Lower Mesozoic . . . . . . . . . . . . . . . 8

Upper Jurassic . . . . . . . . . . . . . . . . 8

Cretaceous _............... 8

Tertiary $\ldots \ldots \ldots \ldots \ldots$

Structure _. $\ldots \ldots \ldots \ldots \ldots \ldots$

Sierra Madre del Sur . . . . . . . . . . . . 19

Sierra Madre Oriental ............... 19

Yucatan platform ................ 20

Gulf Coast Tertiary basins .......... 20

Veracruz basin ............... 20

Isthmus Saline basin . . . . . . . . . 21

Comalcalco basin .............. 21

Macuspana basin .............. 21

Reforma shelf ................... 21

Campeche shelf $\ldots \ldots \ldots \ldots \ldots \ldots \ldots 22$

Offshore salt structure province $\ldots \ldots \ldots \ldots . . .22$

Peten basin ................... 22

Petroleum geology ................... 23

Introduction $\ldots \ldots \ldots \ldots \ldots \ldots$

Tertiary clastic deposits _... . . . . . . . . . 23

Isthmus Saline and Comalcalco basins _. . . 23

Macuspana basin ................ 23
Petroleum geology -Continued

Tertiary clastic deposits -Continued Veracruz basin ................... 24

Reservoirs _. . . . . . . . . . . . . . 24

Source rocks $\ldots \ldots \ldots \ldots \ldots . \ldots 24$

Regional cap rocks ............... 24

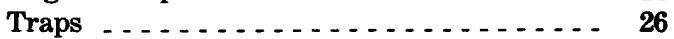

Analogs ... . . . . . . . . . . . . . . 26

Mesozoic and lower Tertiary carbonate complex - 27

Reforma shelf ................. 27

Campeche shelf ................ 27

Rubelsanto area (Guatemala) . . . . . . . . 32

Reservoirs . . . . . . . . . . . . . . . . 34

Source rocks . . . . . . . . . . . . . . 35

Regional cap rocks . . . . . . . . . . . 35

Traps _. $\ldots \ldots \ldots \ldots$

Analogs . . . . . . . . . . . 36

Pre-Oxfordian Mesozoic clastic deposits _. . . . . . 36

Paleozoic rocks . . . . . . . . . . . . . . . . . 36

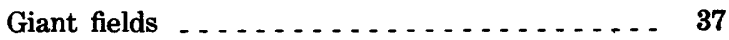

Tertiary basin fields . . . . . . . . . . . 37

Reforma fields .................. 37

Offshore Campeche fields _... . . . . . . 37

Summary 2... . . . . . . . . . . . . . . . 37

Genesis of the petroleum deposits _. . . . 37

Information summary _............. 39

Resource assessment $\ldots \ldots \ldots \ldots \ldots$

Procedures _................... 40

Assessment $\ldots \ldots \ldots$. $1 \ldots \ldots$

Comments

Selected references ..................... 43

\section{ILLUSTRATIONS}

FIGURES 1. Map showing location of southeastern Mexico, northern Guatemala, and Belize assessment region --

2. Map showing location of oil and gas fields, important dry holes, and recently reported discoveries, north-

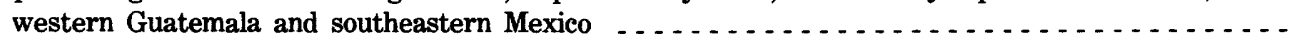

3. Regional structure map of southeastern Mexico, Guatemala, and Belize . . . . . . . . . . . .

4. Stratigraphic correlation chart of southern Mexico and Guatemala . . . . . . . . . . . . . . . . . .

5. South-north structural-stratigraphic cross section $A-A^{\prime}$, southern Chiapas State to offshore Tabasco State, Mexico

6. West-east structural-stratigraphic cross section $A^{\prime}-B$, offshore Tabasco State to Yucatan Peninsula -

7. South-north structural-stratigraphic cross section $C-C^{\prime}$, southern Guatemala to eastern Tabasco State, Mexico

8. West-east structural-stratigraphic cross section $D-D^{\prime}$, Veracruz basin . . . . . . . . . . . . . .

9. Northwest-southeast structural-stratigraphic cross section $E-E^{\prime}$, Sigsbee Knolls area to Yucatan Peninsula 
10. Approximate thickness in meters, partly restored, of pre-Oxfordian Jurassic and Triassic rocks, southeastern Mexico, Guatemala, and Belize . . . . . . . . . . . . . . . . . . . . . . .

11. Approximate thickness in meters, partly restored, Upper Jurassic Oxfordian through Tithonian rocks, southeastern Mexico, Guatemala, and Belize

12. Approximate thickness in meters, partly restored, total Cretaceous rocks, southeastern Mexico, Guatemala, and Belize . . . . . . . . . . . . . . . . . . . . . . . . . . . . . . .

13. Approximate thickness in meters, lower Tertiary (Paleocene, Eocene, and Oligocene) rocks, mostly restored, in Sierra Madre del Sur, Mexico, and Guatemala-Belize areas . . . . . . . .

14. Approximate thickness in meters, upper Tertiary (Miocene and Pliocene) rocks, mostly restored, in Sierra Madre del Sur, Mexico, and Guatemala-Belize areas . . . . . . . . . . . . . . .

15. Structure of top of Miocene Encanto Formation, Cinco Presidentes oil field . . . . . . . . . . . . . .

16. Structure of top of Miocene Amate Formation, Jose Colomo-Chilapilla gas field, Macuspana basin - -

17. Seismic structural map, Reforma area, top of Cretaceous Cenomanian . . . . . . . . . . . . . . . .

18. Structure of top of Upper Cretaceous, A. J. Bermudez Complex oil field, Reforma area . . . . . . .

19. Seismic structural map, offshore Campeche area, top of lower Paleocene . . . . . . . . . . . . . .

20. Structure of Paleocene reservoir section, Cantarell Complex oil field, offshore Campeche area . . . . .

21. Structural cross section $A-A^{\prime}$, Cantarell Complex oil field, offshore Campeche area . . . . . . . . . .

22. Southeast Mexico, northern Guatemala, and Belize recoverable oil … . . . . . . . . . . . .

23. Southeast Mexico, northern Guatemala, and Belize recoverable total gas . . . . . . . . . . . . . . .

\section{TABLES}

TABLE 1. List of main oil and gas fields shown on figure $2 \ldots \ldots \ldots$

2. Data on giant fields assessment area, southeast Mexico $\ldots \ldots \ldots$

3. Generalized stratigraphic columns in Reforma area and offshore Campeche area _... . . . . . . . . .

4. Assessment of conventionally recoverable petroleum resources of southeastern Mexico, northern Guatemala, and Belize $\ldots \ldots \ldots \ldots$

5. Supplementary and comparative data supporting the resource assessment for southeastern Mexico, northern Guatemala, and Belize

\section{ACKNOWLEDGMENTS}

The resource assessment for this report was prepared in collaboration with the Resource Appraisal Group of the USGS Branch of Oil and Gas Resources. 


\title{
Petroleum Geology and Resources of Southeastern Mexico, Northern Guatemala, and Belize
}

\author{
By James A. Peterson
}

\begin{abstract}
Petroleum deposits in southeastern Mexico and Guatemala occur in two main basinal provinces, the Gulf Coast Tertiary basin area, which includes the Reforma and offshore Campeche Mesozoic fields, and the Peten basin of eastern Chiapas State (Mexico) and Guatemala. Gas production is mainly from Tertiary sandstone reservoirs of Miocene age. Major oil production, in order of importance, is from Cretaceous, Paleocene, and Jurassic carbonate reservoirs in the Reforma and offshore Campeche areas. Several small oil fields have been discovered in Cretaceous carbonate reservoirs in west-central Guatemala, and one major discovery has been reported in northwestern Guatemala. Small- to medium-sized oil accumulations also occur in Miocene sandstone reservoirs on salt structures in the Isthmus Saline basin of western Tabasco State, Mexico. Almost all important production is in salt structure traps or on domes and anticlines that may be related to deep-seated salt structures. Some minor oil production has occurred in Cretaceous carbonate reservoirs in a buried overthrust belt along the west flank of the Veracruz basin.

The sedimentary cover of Paleozoic through Tertiary rocks ranges in thickness from about $6,000 \mathrm{~m}(20,000 \mathrm{ft})$ to as much as $12,000 \mathrm{~m}(40,000 \mathrm{ft})$ or more in most of the region. Paleozoic marine carbonate and clastic rocks 1,000 to $2,000 \mathrm{~m}(3,300$ to $6,500 \mathrm{ft}$ ) thick overlie the metamorphic and igneous basement in part of the region; Triassic through Middle Jurassic red beds and evaporite deposits, including halite, apparently are present throughout the region, deposited in part in a Triassic graben system. Upper Jurassic (Oxfordian) through Cretaceous rocks make up the bulk of the Mesozoic regional carbonate bank complex, which dominates most of the area. Tertiary marine and continental clastic rocks, some of deep water origin, 3,000 to $10,000 \mathrm{~m}(10,000$ to $35,000 \mathrm{ft})$ thick, are present in the coastal plain Tertiary basins. These beds grade eastward into a carbonate sequence that overlies the Mesozoic carbonate complex on the Yucatan platform.

During the past 10 years, about 50 large oil fields were discovered in the Reforma and offshore Campeche areas. Oil is produced from intensely microfractured Cretaceous, Paleocene, and Upper Jurassic dolomite reservoirs on blockfaulted salt swells or domes. Most fields are located in the
\end{abstract}

Mesozoic carbonate-bank margin and forebank talus (Tamabra) facies, which passes through the offshore Campeche and onshore Reforma areas. Oil source rocks are believed to be organic-rich shales and shaly carbonate rocks of latest Jurassic and possibly Early Cretaceous age. At least six of the Mesozoic discoveries are giant or supergiant fields. The largest is the Cantarell complex (about 8 billion to 10 billion barrels (BB)) in the offshore Campeche area and the Bermudez complex (about $8 \mathrm{BB}$ ) in the Reforma onshore area. Oil columns are unusually large (from $50 \mathrm{~m}$ to as much as $1,000 \mathrm{~m}$, or $160 \mathrm{ft}$ to $3,300 \mathrm{ft}$ ). Production rates are extremely high, averaging at least 3,000 to 5,000 barrels of oil per day (bo/d); some wells produce more than 20,000 bo/d, particularly in the offshore Campeche area, where 30,000 - to 60,000 -bo/d wells are reported.

Tertiary basin fields produce primarily from Miocene sandstone reservoirs. About 50 of these are oil fields ranging from 1 million barrels (MMB) to $200 \mathrm{MMB}$ in size, located on faulted salt structures in the Isthmus Saline basin. Another 30 are gas or gas-condensate fields of a few billion cubic feet to 3 trillion to 4 trillion cubic feet (Tef) located on salt structures or probable salt structures in the Macuspana, Comalcalco, Isthmus Saline, and Veracruz basins. Source rocks for the gas are believed to be carbonaceous shales interbedded with the sandstone reservoir bodies.

Identified reserves in the southeastern Mexico-Guatemala area, almost all in the Mesozoic fields, are about $53 \mathrm{BB}$ of oil, $3 \mathrm{BB}$ of natural gas liquids, and $65 \mathrm{Tef}$ of gas. The estimated undiscovered resources are about $78 \mathrm{BB}$ of oil and $24 \mathrm{Tcf}$ of gas. Estimated total original recoverable resources (ultimate) are about 177.5 billion barrels of oil equivalent (BBOE). At least 75 onshore structures and more than 150 offshore structures are yet to be tested.

\section{INTRODUCTION}

GEOGRAPHY

The petroleum provinces of southeastern Mexico, northern Guatemala, and Belize cover an area of about $840,000 \mathrm{~km}^{2}\left(325,000 \mathrm{mi}^{2}\right)$, which includes the northern part of Central America and 


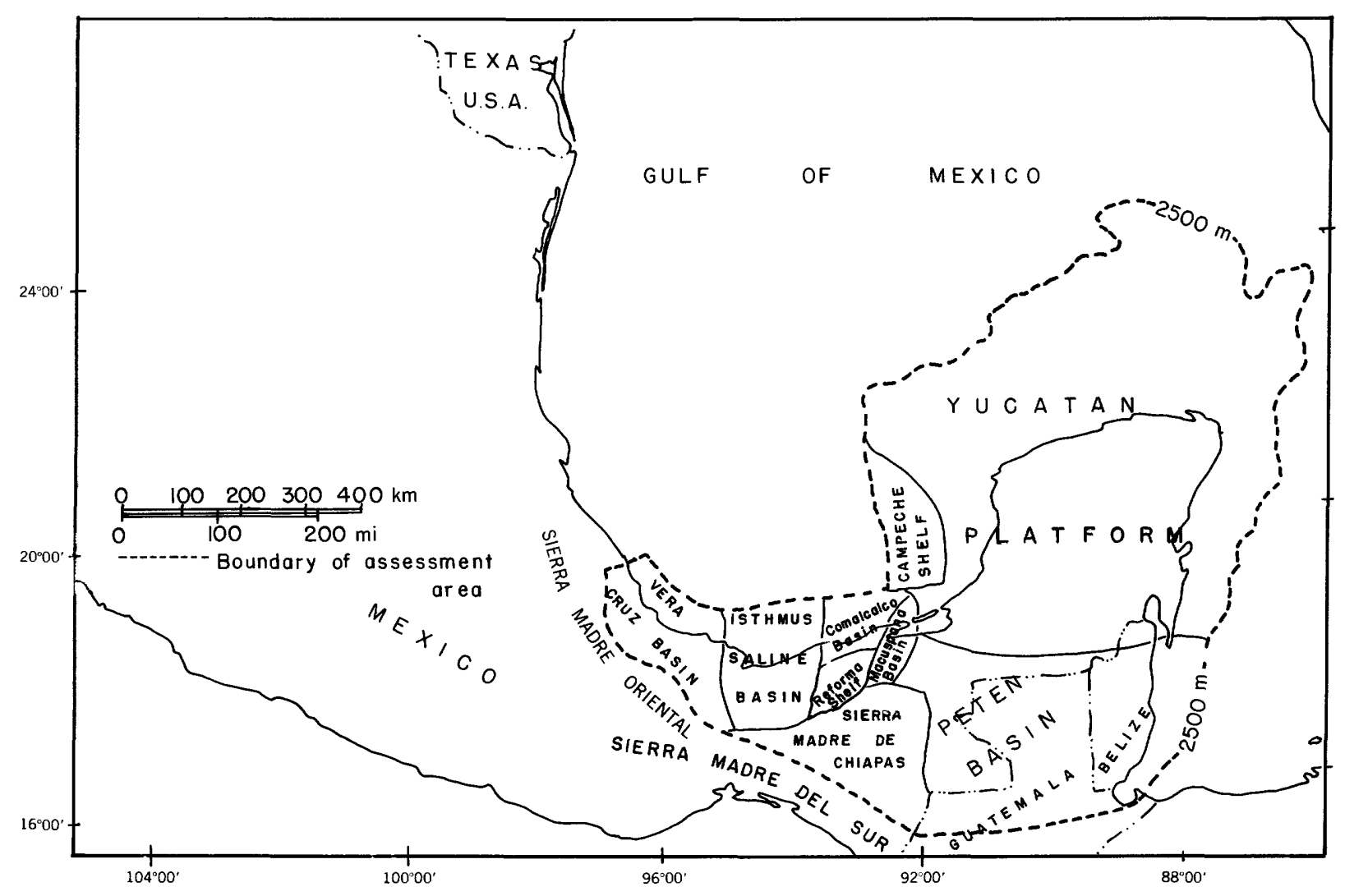

Figure 1.-Location of the southeastern Mexico, northern Guatemala, and Belize assessment region.

the land and offshore area in and adjacent to the southern Gulf of Mexico (figs. 1, 2, 3; table 1). The region includes the southern Gulf coastal plain, the Yucatan Peninsula and the adjacent offshore area of southern Mexico, the Sierra Madre de Chiapas, approximately the northern half of Guatemala, and Belize. The topography of this region ranges from the sea-level Gulf coastal plain and the generally flat, low-relief Yucatan Peninsula to the high-relief Sierra Madre Oriental, the Sierra Madre de Chiapas, the Sierra Madre del Sur, and the ranges of central Guatemala. Climate ranges from tropical rain forest with precipitation of more than $200 \mathrm{~cm} / \mathrm{yr}$ (80 in./yr) in central Chiapas and Guatemala to a savannah climate on the Yucatan Peninsula, where precipation ranges from less than $50 \mathrm{~cm} / \mathrm{yr}(20 \mathrm{in.} / \mathrm{yr}$ ) to about 125 $\mathrm{cm} / \mathrm{yr}$ (50 in./yr). Parts of the area are low lying and swampy, particularly in northern Guatemala and easternmost Tabasco, Mexico. The region lies in the northern equatorial belt between latitudes 15 and $25 \mathrm{~N}$.

\section{SOURCES OF DATA}

Data and information used in preparing this report were compiled primarily from Mexican journals and other publications on petroleum geology and general geology of the area. Of particular value were publications by Viniegra-0. (1971, 1981), Lopez-Ramos (1979), Acevedo and Dautt (1980), Bishop (1980), articles from "The Oil and Gas Journal" and "World Oil," and the information files of Petroconsultants, S.A. Additional references are listed in the section "Selected References."

\section{RECIONAL GEOLOCY}

\section{INTRODUCTION}

The main basins of southeastern Mexico-northern Guatemala (northern Central America) include the Veracruz, Isthmus Saline, Comalcalco, and Macuspana Tertiary basins of the Mexican coastal plain and the Peten basin of Guatemala and east- 


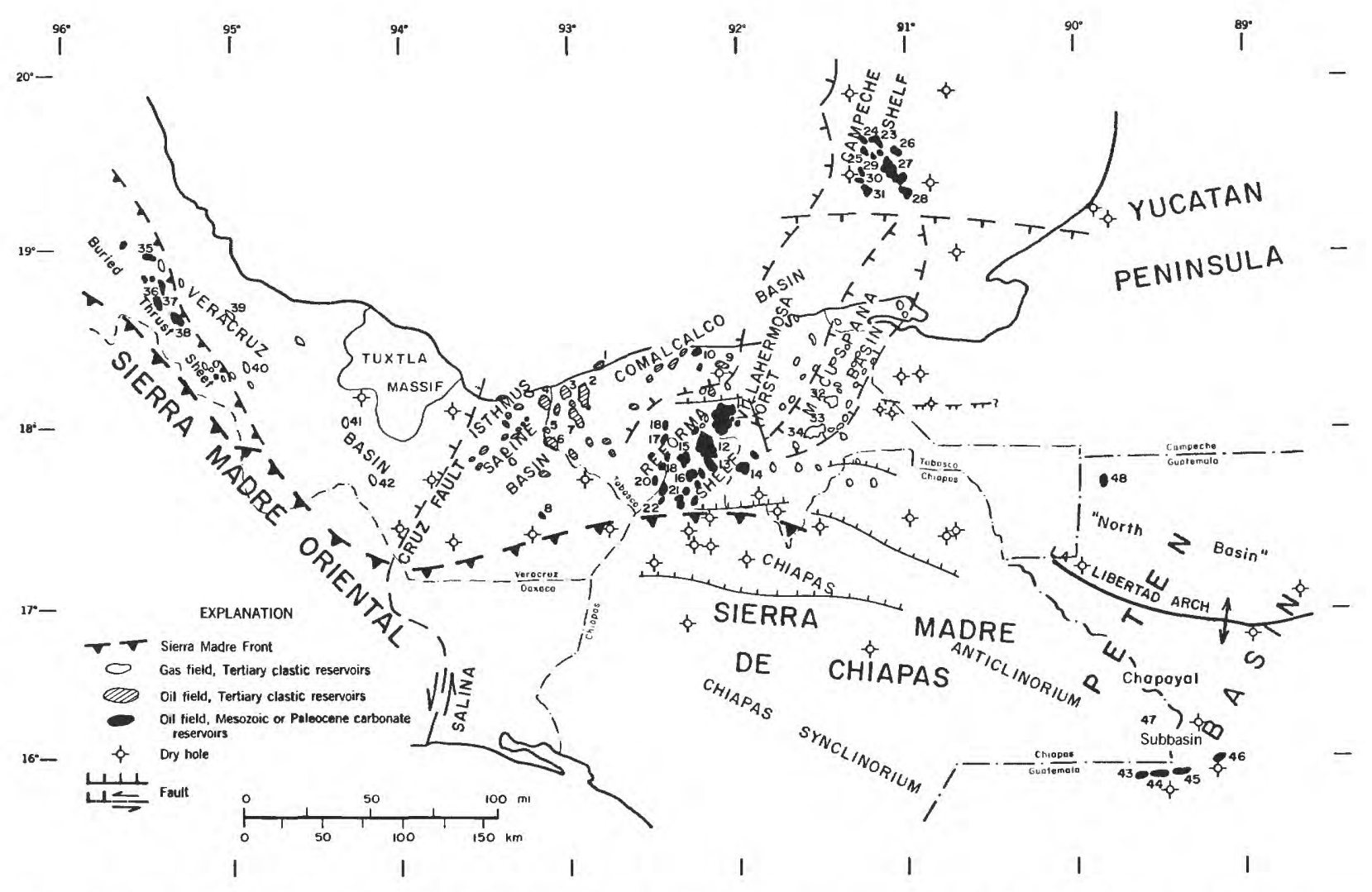

FigURE 2.-Oil and gas fields, important dry holes, and recently reported discoveries (44, 45), northwestern Guatemala and southeastern Mexico. Numbers refer to main oil and gas fields. See table 1 for listing. From Viniegra-O., 1971, 1975a, b, 1981; Mossman and Viniegra-O., 1976; Lopez-Ramos, 1979; Acevedo and Dautt, 1980; Bishop, 1980; and Petroconsultants.

ern Chiapas, Mexico. The Veracruz, Isthmus Saline, Comalcalco, and Macuspana basins contain thick deposits of Cenozoic marine clastic deposits (fig. 4) and extend northward into the offshore area of the southern Gulf of Mexico where they merge with the main offshore salt structure province. This coastal plain Tertiary basin province is bounded on the south by the front ranges of the Sierra Madre Oriental and the Sierra Madre de Chiapas fold and fault belt, which contain extensive exposures of thick Cretaceous carbonate rocks, narrow infolded bands of Tertiary clastic rock remnants, and some Cenozoic igneous bodies. The mountainous area to the south (the Sierra Madre del Sur) is an elongate belt of Paleozoic or Precambrian intrusive and metamorphic rocks and of Cenozoic volcanic rocks. This belt includes the Chiapas Massif of Mexico and the fault-bounded igneous and metamorphic province of southern Guatemala. The Peten basin lies north of the Polochic fault zone (which forms the northern boundary of the Guatemalan metamorphic, intru- sive, and volcanic belt). This basin includes the Chapayal and north subbasins, which are separated by the east-trending La Libertad anticline (arch) (fig. 2). The Yucatan platform in the northeastern part of the province includes the Yucatan Peninsula and the surrounding shallow-water offshore shelf extending approximately out to the $200-\mathrm{m}$ (650-ft) water depth. The platform is bounded by a steep underwater escarpment, with relief of 2,000 to $3,000 \mathrm{~m}(6,500$ to $10,000 \mathrm{ft})$; the escarpment is particularly prominent on the northwestern, northern, and eastern sides of the platform. The southwestern part of the Yucatan platform includes the Campeche shelf, which contains the major offshore petroleum deposits of the area. The salt structure province covers a large segment of the southwestern Gulf of Mexico including the offshore Campeche production area (fig. 3) and extends southward onshore to include the main area of Tertiary oil and gas fields in the Isthmus Saline basin and the giant Cretaceous oil fields in the Reforma area (fig. 2, table 1). 


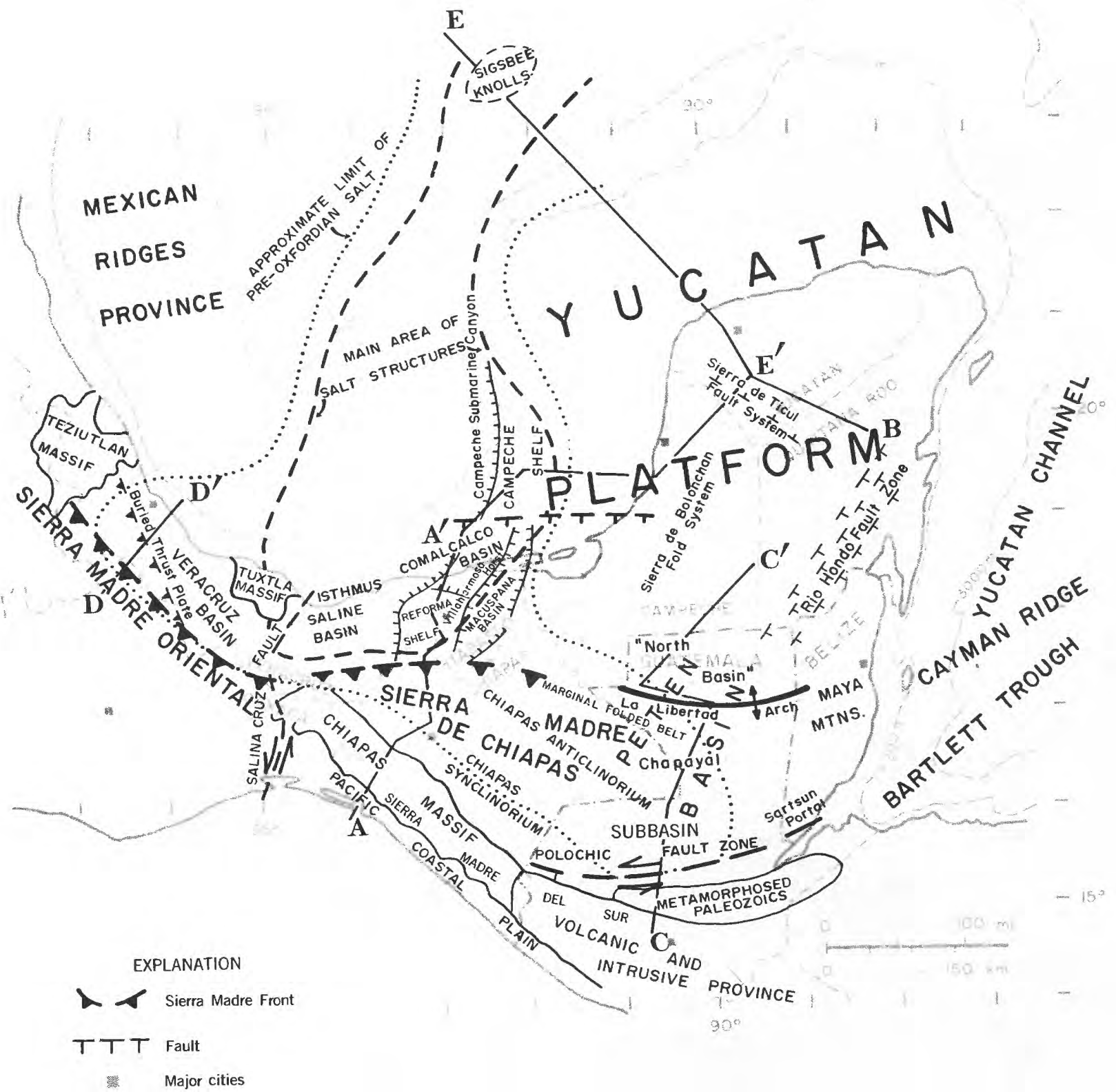

Figure 3.-Regional structure map of southeastern Mexico, Guatemala, and Belize. From Viniegra-O., 1971, 1975a; Dengo and Bohnenberger, 1969, Mossman and Viniegra-O., 1976; Lopez-Ramos, 1979; Bishop, 1980; and Martin, 1980.

\section{STRATIGRAPHY}

The basement complex of the appraisal area consists of Precambrian and lower to middle Paleozoic igneous and metamorphic rocks, which are overlain by a thick section of upper Paleozoic, Mesozoic, and Cenozoic sedimentary rocks (see figs. 4-9) (Viniegra-O., 1971, 1981; Lopez-Ramos,
1979; Bishop, 1980). Sedimentary rocks of late Paleozoic age are locally metamorphosed in outcrops in the southern part of the region, but little is known of their character in the subsurface, where they have been penetrated by relatively few wells. The total sedimentary cover in the Sierra Madre de Chiapas, northern Guatemala, Belize, and on the Yucatan platform is about 3,000 
TABLE 1.-List of main oil and gas fields shown in figure 2

[Number in parentheses following oil or gas field name corresponds to oil or gas field number used in figure 2]

Isthumus Saline basin

Comalcalco basin

\section{Reforma area}

Offshore Campeche

Macuspana basin

Veracruz basin

Peten basin

\section{Santa Ana (1)}

Magallanes-San Ramon (2)

Cinco Presidentes (3)

Tonala (4)

Soldadas (5)

El Plan (6)

Ogarrio-Otates (7)

Nanchital (8)

Mecoacan (9)

Arrastradero )10)

\author{
A. J. Bermudez Complex (11) \\ Cactus (12) \\ Sitio Grande (13) \\ Agave (14) \\ Cacho Lopez (15) \\ Mundo Nuevo (16) \\ Paredon (17) \\ Iris (18) \\ Fenix (19) \\ Giraldas (20) \\ Sunapa (21) \\ Copano (22)
}

Bacaab (23)

Maloob (24)

$\mathrm{Ku}$ (25)

Ek (26)

Cantarell Complex (27)

Takim (28)

Ixtoc (29)

Kanaab (30)

Abkatun (31)

Hormiguero (32)

Jose Colomo (33)

Chilapilla (34)

Tres Higueras (35)

Mata Pionche (36)

Casa Blanca (37)

Angostura (38)

Cocuite (39)

Mirador (40)

Mata Verde (41)

Jesus Carranza-1 (42)

Tortugas (43)

Rubelsanto (44)

Chinaja (45)

Hispanoil 1981 discovery, Yalpemech No. 1 (46)

Tertiary-Mesozoic discovery, 1979? (47)

Northwest Guatemala Texaco discovery, 1981, Xan No. 1 (48) 


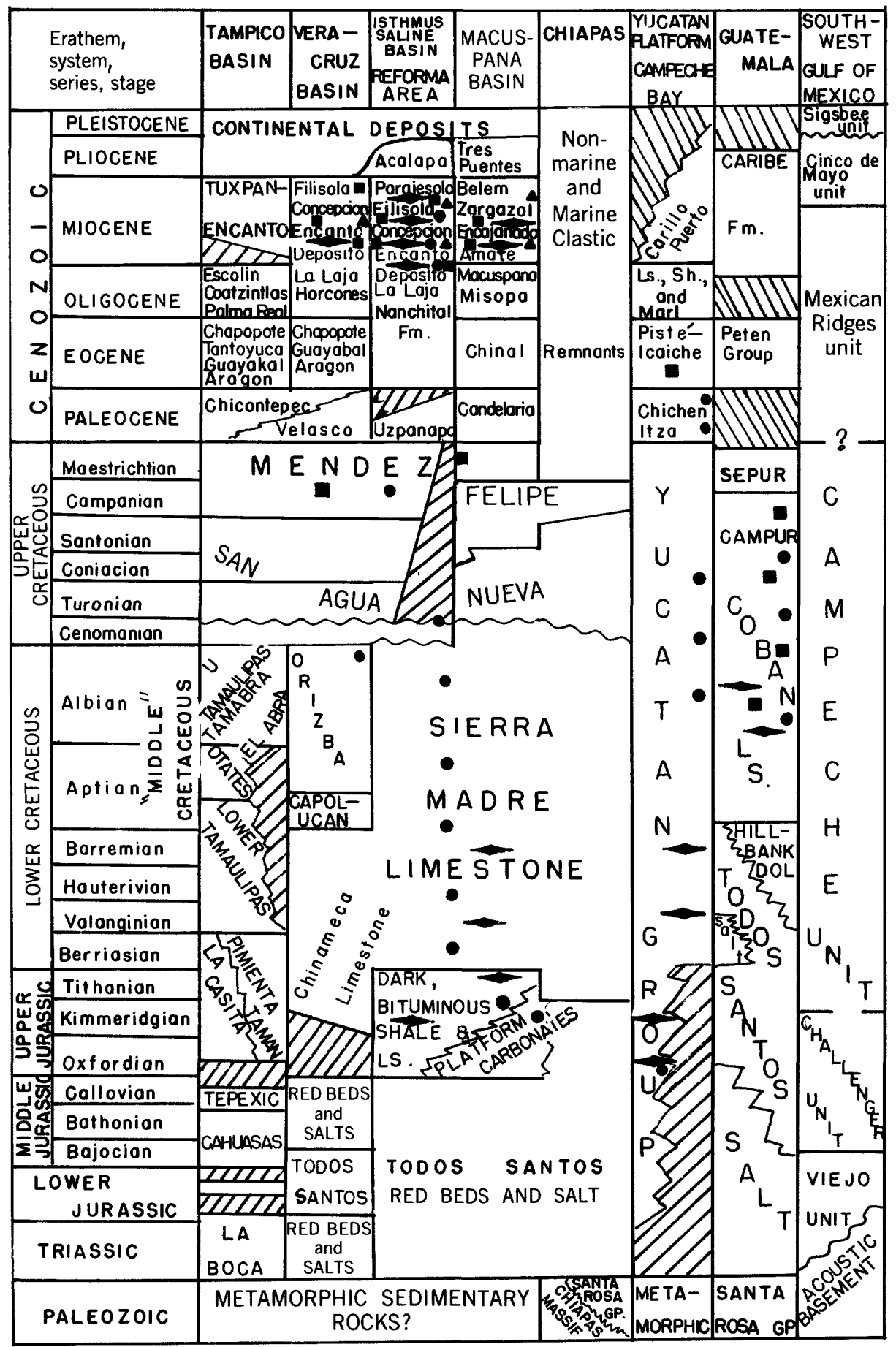

\section{EXPLANATION \\ Oil Production \\ $\Delta$ Gas Production \\ - Source Rock}

FIGURE 4.-Stratigraphic correlation chart of southern Mexico and Guatemala. From Vinson, 1962; Richards, 1963; Viniegra-O., 1971; Burkart and others, 1973; Clemons and others, 1974; Lopez-Ramos, 1979; and Bishop, 1980. 

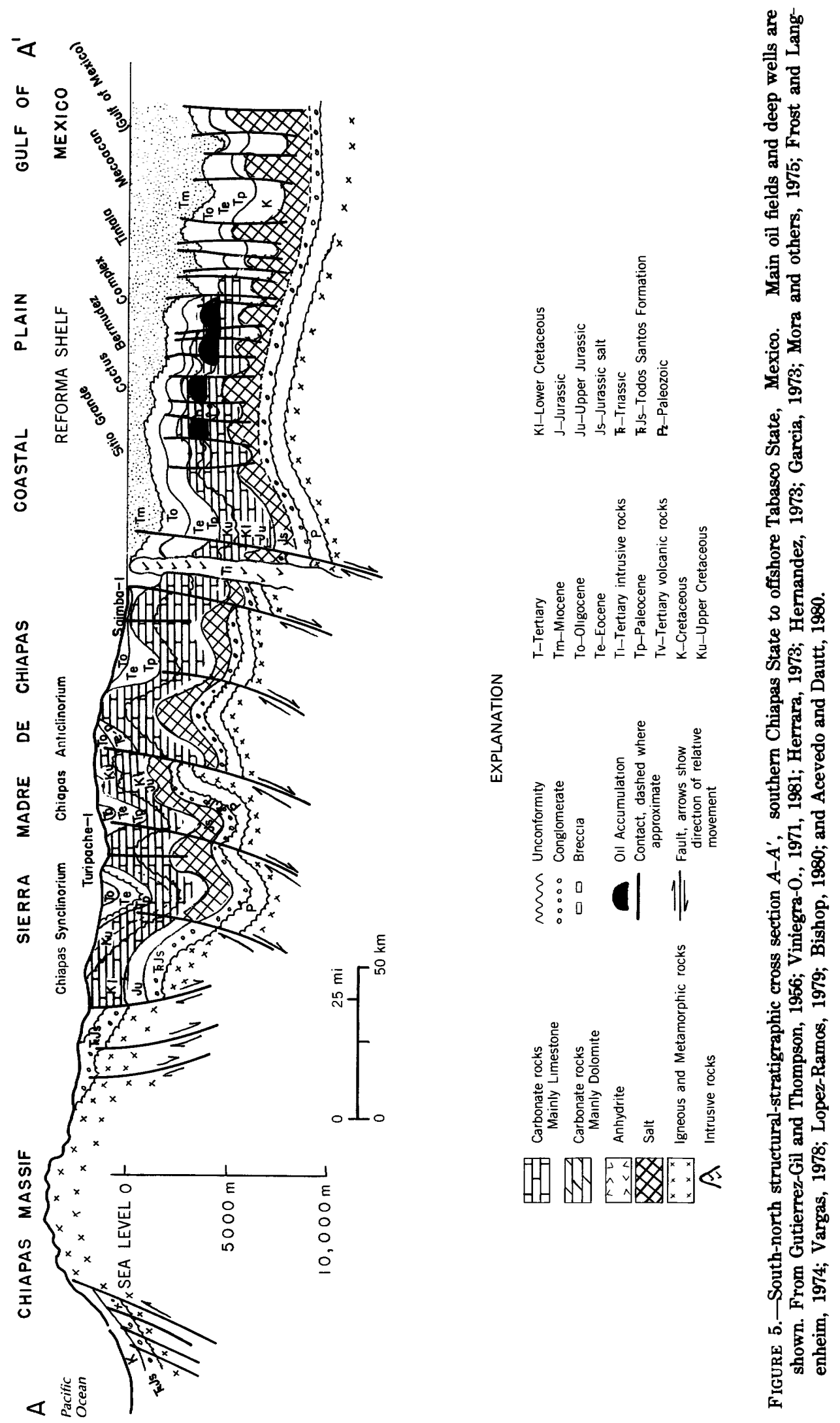
to $10,000 \mathrm{~m}(10,000$ to $35,000 \mathrm{ft})$ thick and consists largely of Mesozoic carbonate and evaporite rocks (figs. 10-12). Tertiary carbonate rocks overlie Mesozoic carbonate and evaporite rocks on the Yucatan platform. Mesozoic rocks are thinner in the subsurface of the Gulf coastal plain but are overlain by a thick section of Tertiary marine clastic rocks. The total thickness of the sedimentary cover in the coastal plain basins, primarily of marine Tertiary rocks, is at least $6,000 \mathrm{~m}(20,000$ $\mathrm{ft}$ ) in most places and ranges as high as $10,000 \mathrm{~m}$ $(35,000 \mathrm{ft})$ or more (figs. 13,14$)$.

\section{PALEOZOIC}

An unknown thickness of marine Paleozoic carbonate and clastic rocks, which are metamorphosed in varying degrees, underlies the Mesozoic in most of the region (figs. 4, 5, 7). These rocks comprise the Santa Rosa Group in Guatemala and eastern Chiapas, Mexico, where relatively unmetamorphosed sequences are present. The Santa Rosa Group consists of marine fossiliferous Permian and Pennsylvanian carbonate, dark shale, and sandstone beds that are considered to have petroleum potential (Garcia, 1973; Bishop, 1980).

\section{LOWER MESOZOIC}

Rocks of late Paleozoic age are overlain unconformably by red beds and conglomerates of the Todos Santos Formation, which grade upward to intertonguing red beds and evaporite deposits, including halite, of probable Middle to Late Jurassic age. The Todos Santos is $1,000 \mathrm{~m}$ or more $(\geqq 3,300$ $\mathrm{ft}$ ) thick in parts of Guatemala, Chiapas, the coastal plain, and offshore Campeche areas (fig. 10). Clastic source areas for these sediments were the Chiapas Massif and uplifts in southern Guatemala, Belize, and possibly eastern Yucatan. The conglomerate facies is thickest in Guatemala and southeastern Chiapas, where it is observed to fill grabenlike troughs of probable Triassic age.

The known or projected distribution of pre-Oxfordian Jurassic salt and the area of important salt structures are shown in figure 10. The precise age and the original depositional thickness of the salt section are not known; it may have been deposited at different times in the early Mesozoic basins of southern Mexico and Guatemala (fig. 4). Thickness patterns must have been influenced by the position of local areas of subsidence, such as the early
Mesozoic grabenlike troughs where large thicknesses of both red beds and salt probably accumulated. Some authors believe that the present distribution of known salt structures generally coincides with the areas of greater salt deposition (Bishop, 1980). Viniegra-O. (1981) shows five areas of maximum salt accumulation, two of which are offshore and three onshore in eastern Veracruz, Tabasco, and Chiapas, Mexico.

\section{UPPER JURASSIC}

Upper Jurassic beds are as much as $1,000 \mathrm{~m}$ or more ( $\geqq 3,300 \mathrm{ft}$ ) thick (fig. 11) and represent the early development (Oxfordian) of the platform carbonate facies that dominated the area through the remainder of Mesozoic time (Great Carbonate Bank of Yucatan) (Viniegra-O., 1981). The exact distribution of the Upper Jurassic platform carbonate belt is not known, but the platform facies has been penetrated in the Reforma and offshore Campeche wells. The facies also may be present around the border of the Yucatan platform and may extend westward along the south flanks of the Isthmus Saline and Veracruz basins and probably into eastern Chiapas and central Guatemala. This section contains a substantial thicl.ness of oolitic and bioclastic carbonate beds similar to the limestone facies of the Smackover Formation of the U.S. Gulf Coast and northern Mexico. Back-bank evaporite beds, possibly including some halite, are present in Guatemala and eastern Chiapas.

In the coastal plain and offshore Gulf of Mexico, the carbonate bank facies grades into and is overlain by organic-rich, deeper water black shale and shaly limestone beds. The upper part of this section extends southward into Chiapas, and possibly Guatemala, and is believed to be the main sourcerock section for oil in the Reforma and offshore Campeche fields.

\section{Cretaceous}

Shelf carbonate rocks of Cretaceous age as much as $3,000 \mathrm{~m}$ or more $(\geqq 10,000 \mathrm{ft})$ thick make up the major part of the Great Carbonate Bank of Yucatan (figs. 4, 12). Three carbonate facies, similar to those of the Tampico basin-Golden Lane area, have been recognized (Viniegra-O., 1981) in the southeastern Mexico region: (1) the El Abra facies, which includes the relatively narrow plat- 
form-edge reef belt and the associated widespread back-reef fine-grained carbonate and evaporite beds, (2) the Tamabra facies, which comprises a relatively narrow belt of forereef talus or slump breccia on the seaward border of the El Abra facies, and (3) the Tamaulipas facies, a deeper water basinal facies of fine-grained argillaceous limestone and limy shale. The back-reef El Abra facies occupies the entire Yucatan platform, much of Guatemala, and the Sierra Madre de Chiapas. The main reef belt of this facies is believed to be present around the entire periphery of the platform as far south as northern Belize. From here, its distribution is not well known, but it may extend to the west from Belize across Guatemala and the Sierra Madre de Chiapas in more than one belt (Viniegra-O., 1975b, 1981; Bishop, 1980; Garcia, 1978). The reef and forereef breccia facies passes through the offshore Campeche area and continues along the platform border through the Reforma area. From there, it is projected to continue westward along the southern border of the Isthmus Saline and Veracruz basins (Viniegra-O., 1981). The reef rocks of the El Abra facies are composed of rudist, coral, and other shell debris and are commonly dolomitized, particularly in the western Yucatan and Reforma areas. These beds are similar in composition to the Edwards and associated reef facies of the U.S. Gulf of Mexico area and northern Mexico. Reef growth was greatest in the "middle" Cretaceous (Aptian-Albian and Cenomanian), which is overlain unconformably by Upper Cretaceous beds. The unconformity represents a period in which the Cretaceous reef section underwent widespread emergence, karstification, possibly dolomitization, and erosion, with the consequent development of erosional debris accumulations, particularly on the seaward side of the reef belt. At this time, a carbonate detritus or calcarenite fan was deposited in the Reforma area (Viniegra-O., 1981), where these beds make up an important part of the productive reservoir section. The Tamabra reef-talus facies has been recognized in the subsurface of the Reforma and offshore Campeche districts, where it is a major reservoir facies. The facies is projected to be present along most of the oceanward border of the reef belt. The Tamaulipas basinal facies is reported in wells in the northern part of the Reforma and the western part of the Campeche productive areas and is believed to be widely distributed in the Gulf of Mexico basinward of the reef facies.

Rocks of Late Cretaceous age (Agua Nueva, San Felipe, and Mendez Formations) are mainly pelagic marine marl and calcareous shale in the Mexico coastal plain region. To the south, in the Sierra Madre de Chiapas and central Guatemala, part of the Upper Cretaceous section is absent in places because of Cenozoic erosion. However, fossiliferous bank carbonate deposits are recognized in outcrops and in the subsurface in Guatemala and Chiapas, and shelf limestone, dolomite, and anhydrite beds are present in Yucatan, indicating the continued deposition of the El Abra facies during this time. Nearshore clastic beds are reported at the top of the Cretaceous (Campanian-Maestrichtian) in Guatemala and southern Chiapas (Bishop, 1980), and Paleocene clastic rocks locally overlie "middle" Cretaceous carbonate rocks in the Reforma subsurface (Viniegra-O., 1981).

\section{TERTIARY}

Rocks of Tertiary age are believed to be as much as 8,000 to $10,000 \mathrm{~m}$ ( 25,000 to $35,000 \mathrm{ft}$ ) thick in the coastal plain and nearby offshore Gulf area of Tabasco and Veracruz (figs. 13, 14). In this area, Tertiary beds are primarily a fine-grained offshore marine clastic facies, which grades southward into coarser grained marine sandstone, conglomerate, and shale in the Veracruz, Isthmus Saline, and Macuspana basins and finally to coarse-grained continental and nearshore marine beds in the Sierra Madre provinces of Veracruz and Chiapas and in central Guatemala (figs. 13, 14). Thick, lower Tertiary, deepwater beds with turbidite deposits are common toward the basin centers. This facies grades upward to shallowwater nearshore deposits in the Miocene, which contain the main reservoir sand facies in the coastal plain basins.

Tertiary beds are absent in much of the Sierra Madre and Guatemala areas because of middle to late Cenozoic erosion but are preserved in elongate northwest-trending downwarped belts in the fold and fault belt of Chiapas. Mixed continental and marine beds of early and late Tertiary age are described in outcrop areas north of the Chiapas Massif (Frost and Langenheim, 1974; LopezRamos, 1979) and in Guatemala (Vinson, 1962; Clemons and Burkart, 1971; Burkart and others, 


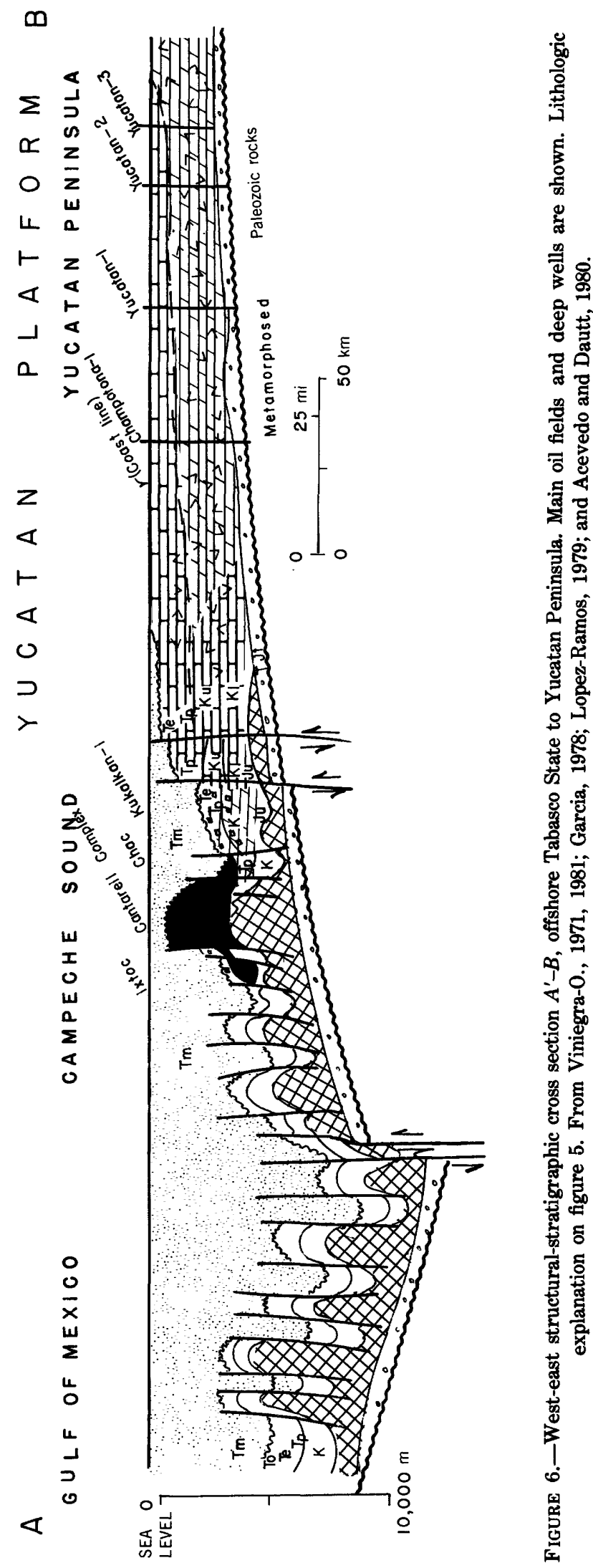



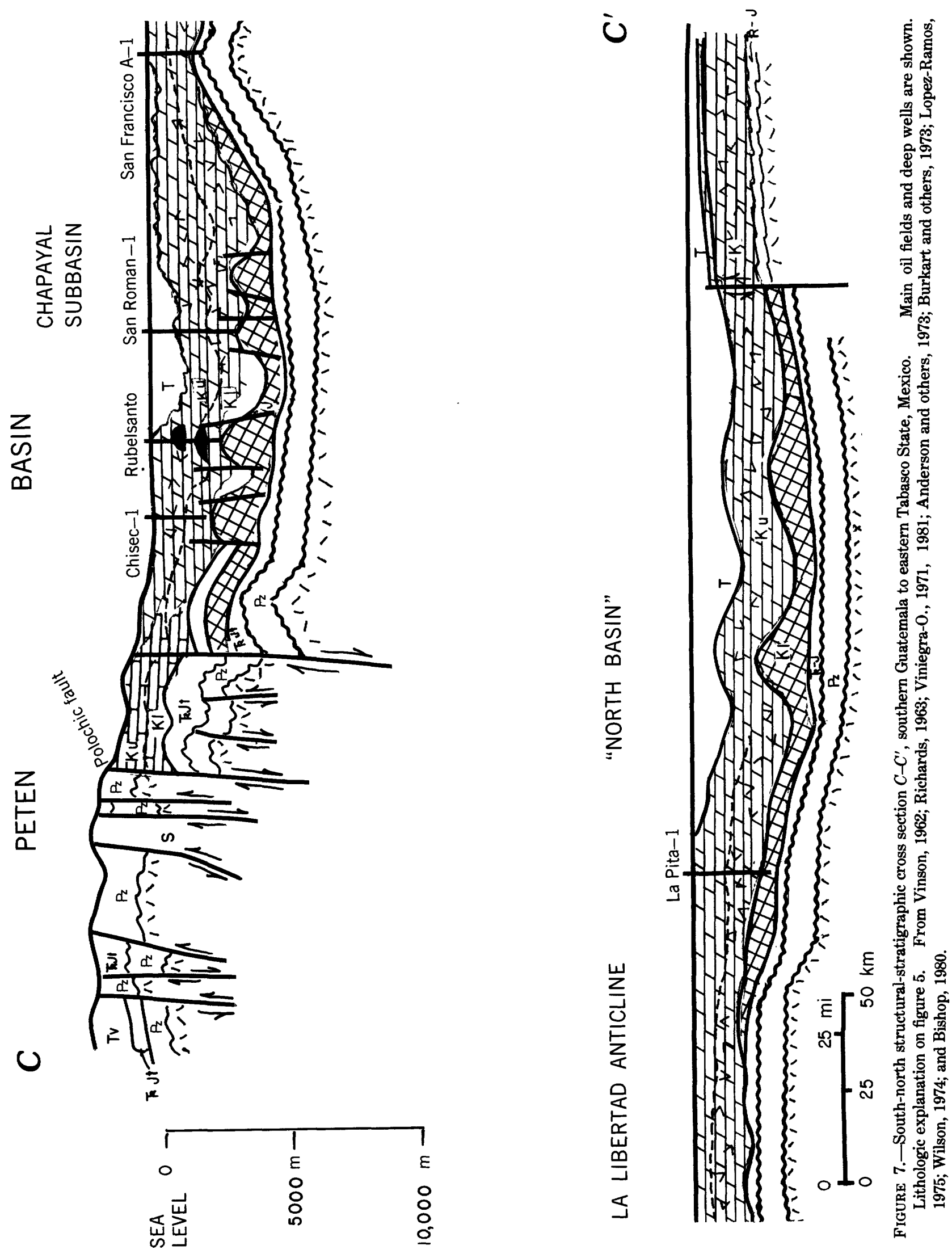


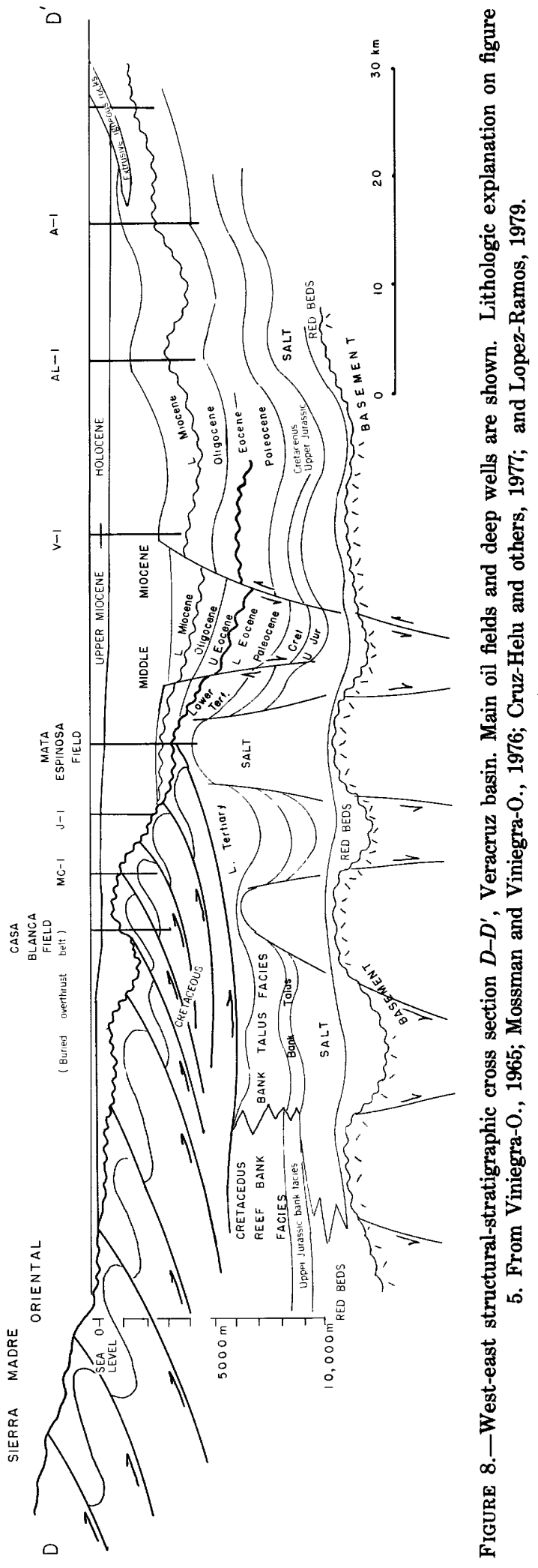




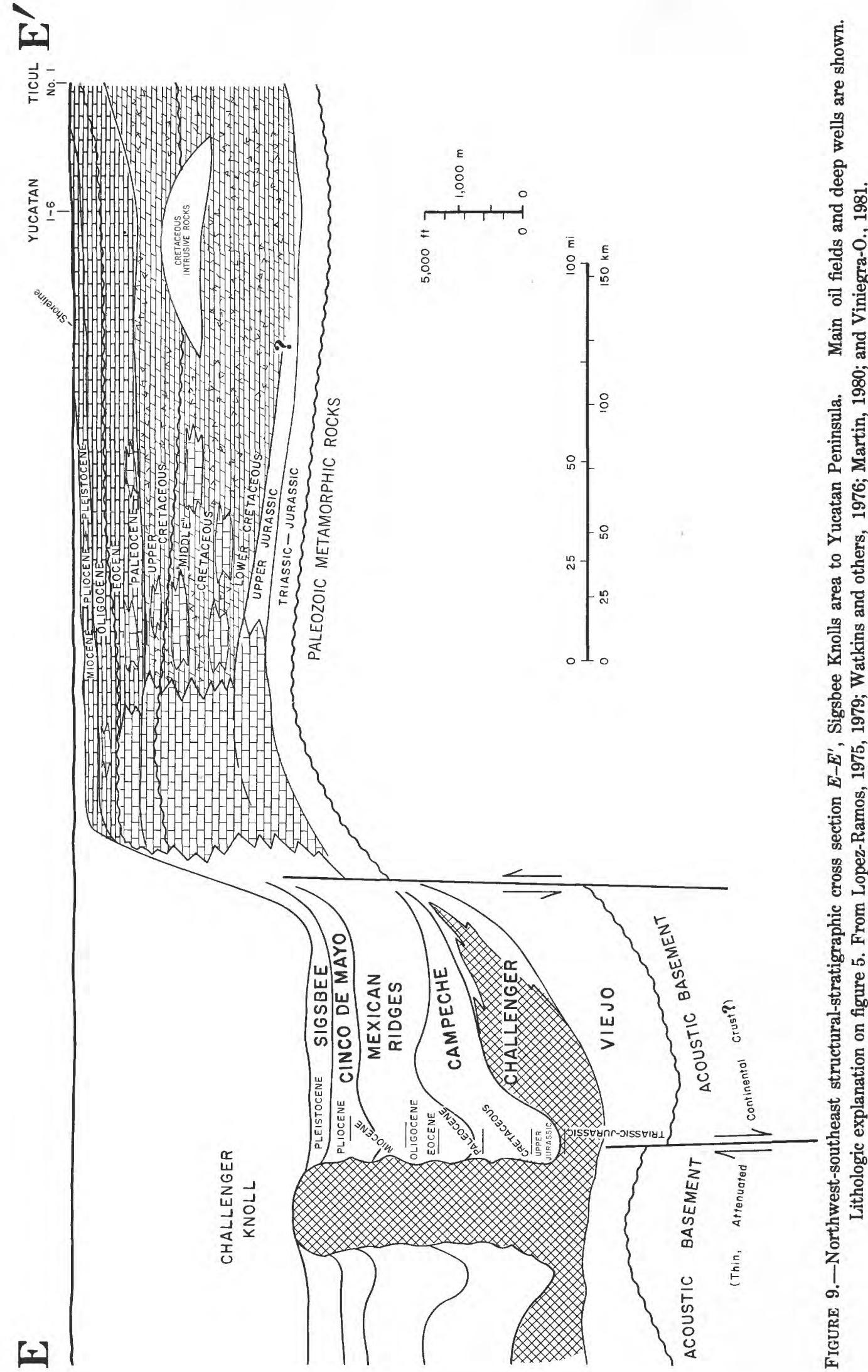




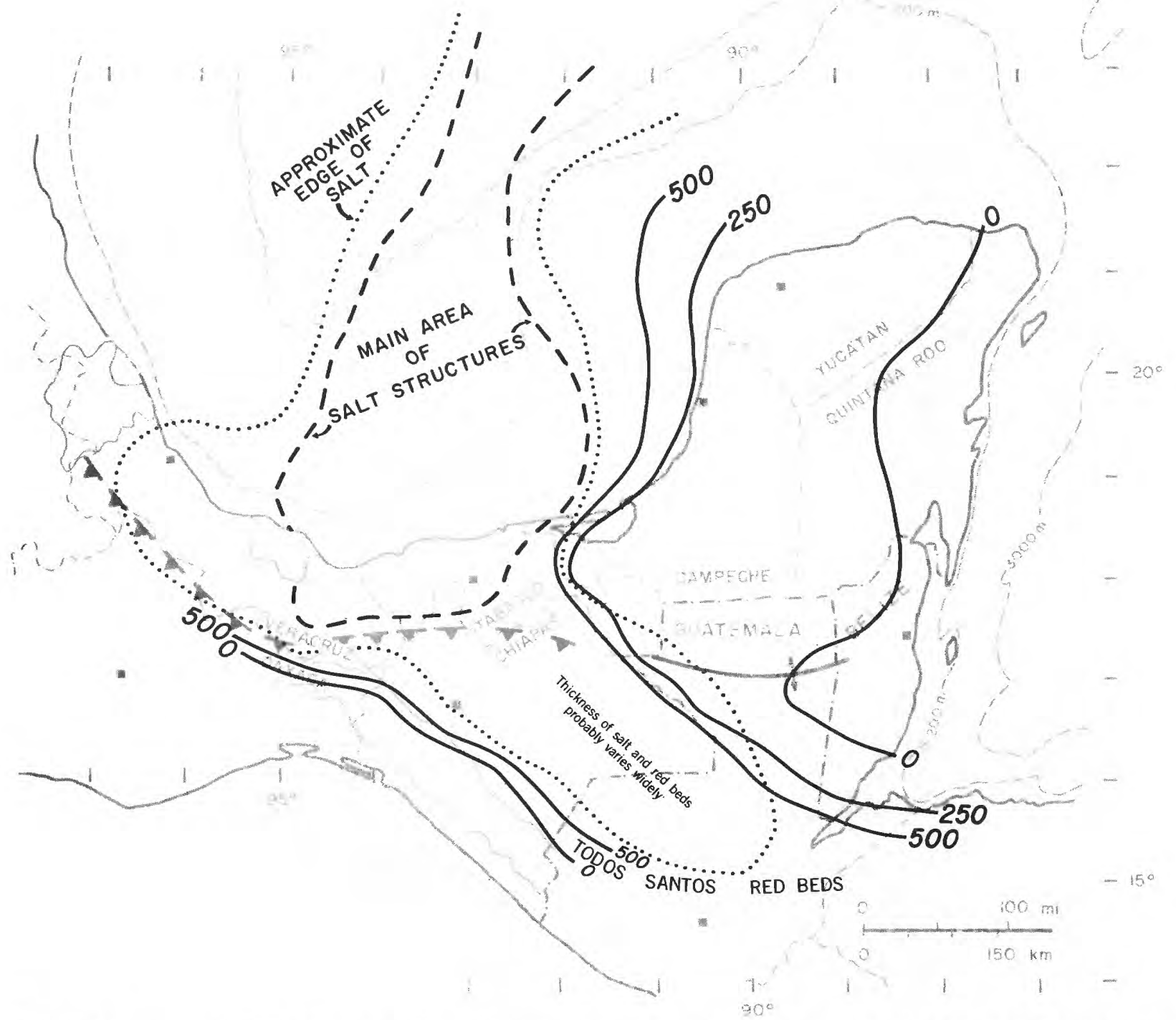

FIGURE 10.-Approximate thickness in meters, partly restored, of pre-Oxfordian Jurassic and Triassic rocks, southeastern Mexico, Guatemala, and Belize. From Viniegra-O., 1971, 1975a, 1981; Lopez-Ramos, 1975, 1979; Bishop, 1980 ; Martin, 1980.

1973). Restored-thickness maps indicate that original depositional thickness of lower Tertiary rocks (Paleocene, Eocene, and Oligocene) was greatest in a northwest-trending elongate foredeep trough north of the Chiapas Massif $(>5,000 \mathrm{~m}$ or $>16,000$ $\mathrm{ft}$ ), whereas the upper Tertiary (Miocene and younger) beds are thickest $(>6,000 \mathrm{~m}$ or $>20,000$ $\mathrm{ft}$ ) in the coastal plain area of Tabasco (figs. 13, 14). These thickness relations are compatible with the concept of a northward-shifting depositional axis as the Laramide tectonic belt developed.
The Tertiary clastic facies becomes progressively more calcareous toward the east. On the Yucatan platform, Tertiary beds are primarily carbonate rocks and marls with some evaporite deposits. These beds represent continued building of the great carbonate bank of Yucatan during the Tertiary. The platform-edge reef belt of the platform border remained in essentially the same position during Tertiary time, and reef growth continued in much of the belt into Holocene time. Paleocene and possibly Eocene reef and forereef 


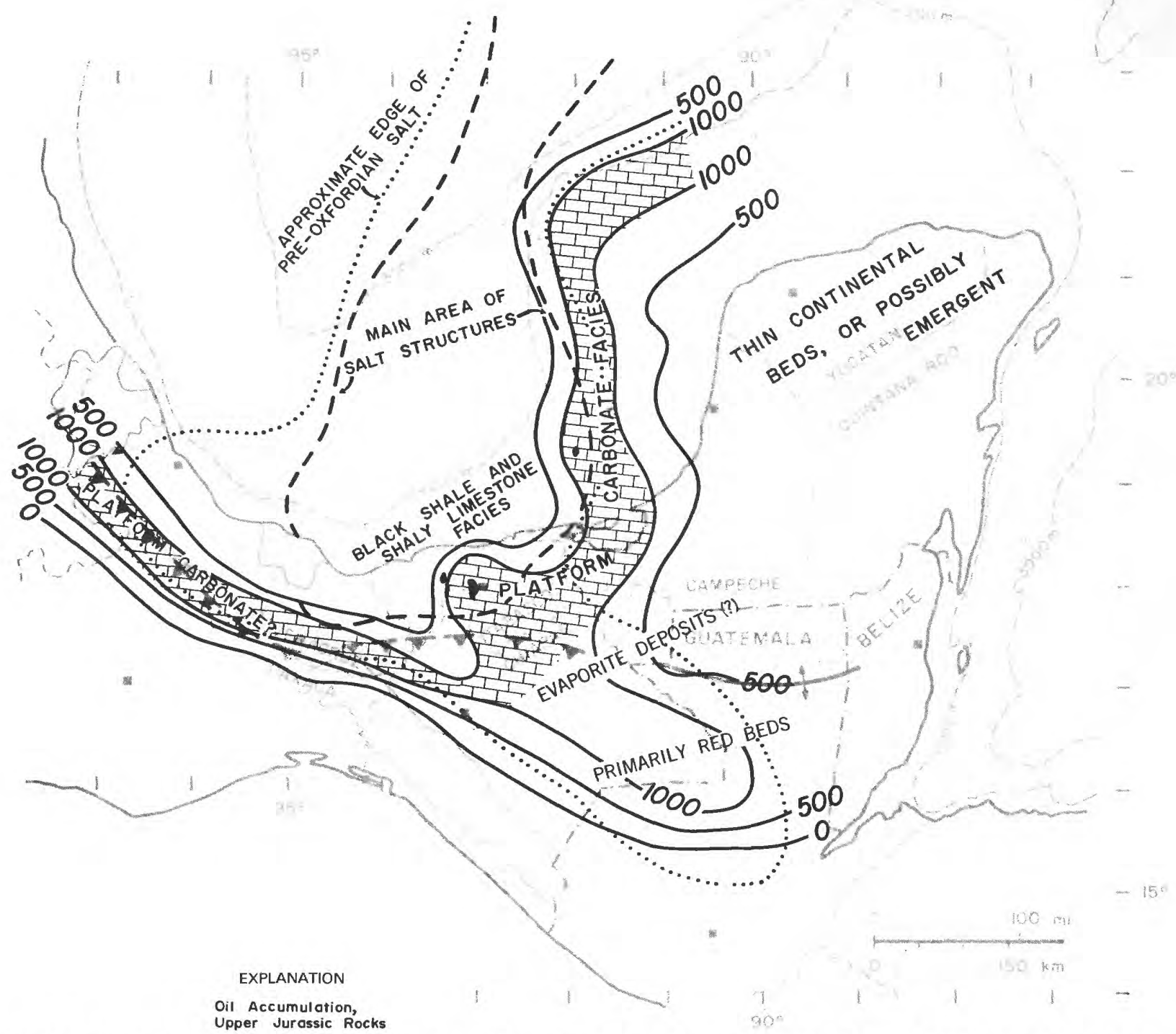

FiguRe 11.-Approximate thickness in meters, partly restored, Upper Jurassic Oxfordian through Tithonian rocks, southeastern Mexico, Guatemala, and Belize. From Viniegra-O., 1971, 1975a, 1981; Lopez-Ramos, 1975, 1979; Bishop, 1980 ; and Martin, 1980.

talus facies have been penetrated in offshore Campeche wells, where these beds make up an important part of the reservoir facies. The Tertiary carbonate facies covers the entire Yucatan platform and grades westward to fine-grained, deeper water clastic rocks west of the Campeche shelf and approximately along the eastern border of Tabasco. Southward, the carbonate facies grades into clastic beds just south of the La Libertad arch in Guatemala (fig. 13). Upper Tertiary rocks are absent on much of the Yucatan Peninsula, apparently owing to post-Oligocene emergence.

\section{STRUCTURE}

The structural complexity of the southeastern Mexico, Guatemala, and Belize area has evolved through at least seven episodes of tectonic activity (Viniegra-O., 1971, 1981; Bishop, 1980; Dengo and Bohnenberger, 1969; Paine and Meyerhoff, 1970): 


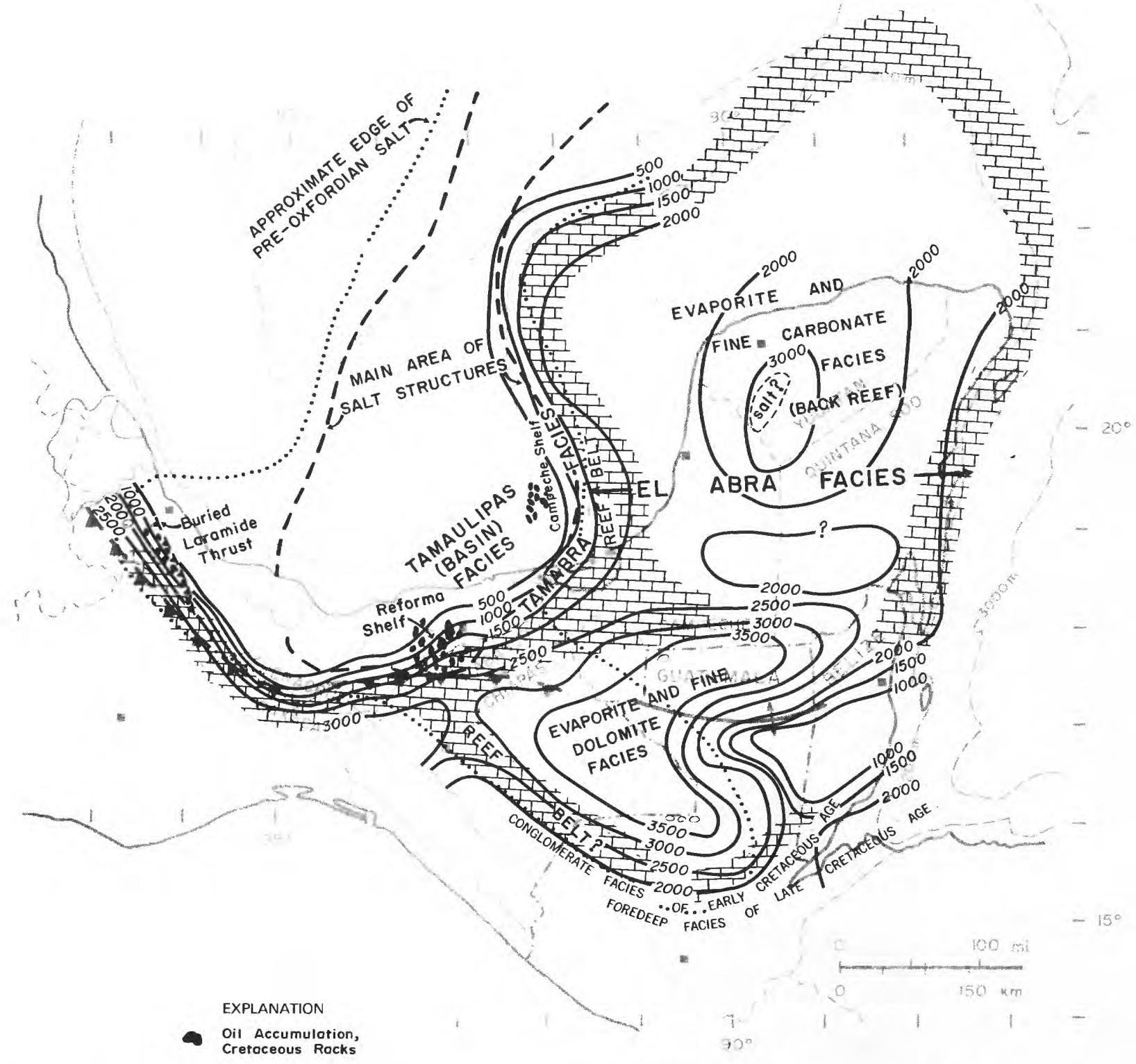

FIGURE 12.-Approximate thickness in meters, partly restored, total Cretaceous rocks, southeastern Mexico, Guatemala, and Belize. From Vinson, 1962; Richards, 1963; Viniegra-O., 1971, 1975a, 1981; Burkart and others, 1973; Anderson and others, 1973; Wilson, 1974; Lopez- Ramos, 1975, 1979; Mora and others, 1975; and Bishop, 1980.

1. Middle Paleozoic (Devonian?) tectonic and igneous activity with batholith emplacement in the Chiapas metamorphic complex (Guzman and de Cserna, 1963).

2. Late Paleozoic (Pennsylvanian-Permian) tectonic and igneous activity with folding and metamorphism in some areas.

3. Triassic to Middle Jurassic uplift, together with formation of intermontane grabens, and associated volcanic activity in the Sierra Madre del Sur area and deposition of thick red bed and evaporite sequences in the depressions.

4. Late Jurassic to Late Cretaceous development of the Mesozoic geosyncline and platform and an associated uplift belt along the Sierra Madre del Sur belt. Slow subsidence of platform areas in a major part of eastern 


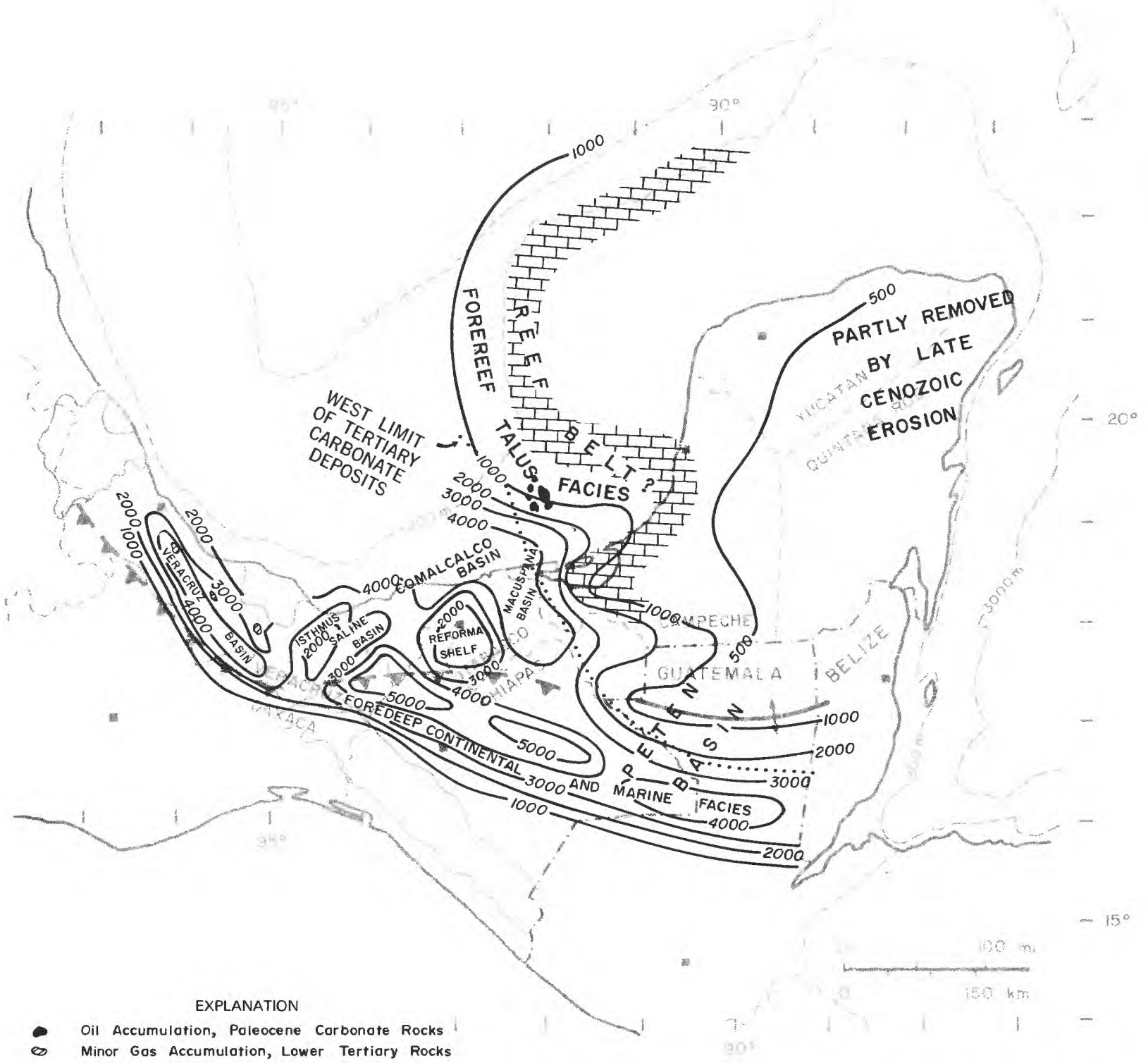

FiguRE 13.-Approximate thickness in meters, lower Tertiary (Paleocene, Eocene, and Oligocene) rocks, mostly restored, in Sierra Madre del Sur, Mexico, and Guatemala-Belize ares. From Castillo, 1955; Vinson, 1962; Viniegra-0., 1965, 1971, 1975a; Burkart and others, 1973; Frost and Langenheim, 1974; Mossman and Viniegra-O., 1976; Cruz-Helu and others, 1977; and Lopez-Ramos, 1979.

Mexico, Guatemala, Belize, and the Yucatan platform occurred, with associated deposition of the thick platform carbonate sequence. In Chiapas and Guatemala, a narrow foredeep immediately north of the southern land mass was present during Jurassic and Early Cretaceous time.

5. Possible "middle" Cretaceous orogeny and igneous intrusion along the Sierra Madre del Sur belt (Paine and Meyerhoff, 1970).

6. Late Cretaceous-early Tertiary (Laramide) orogeny (the Mexican orogeny) with uplift of the Sierra Madre del Sur and folding and thrust faulting directed north or northeast and decreasing northward in the Sierra Madre Oriental and Sierra Madre de Chiapas. Tectonic activity of this phase culminated in the Eocene. 


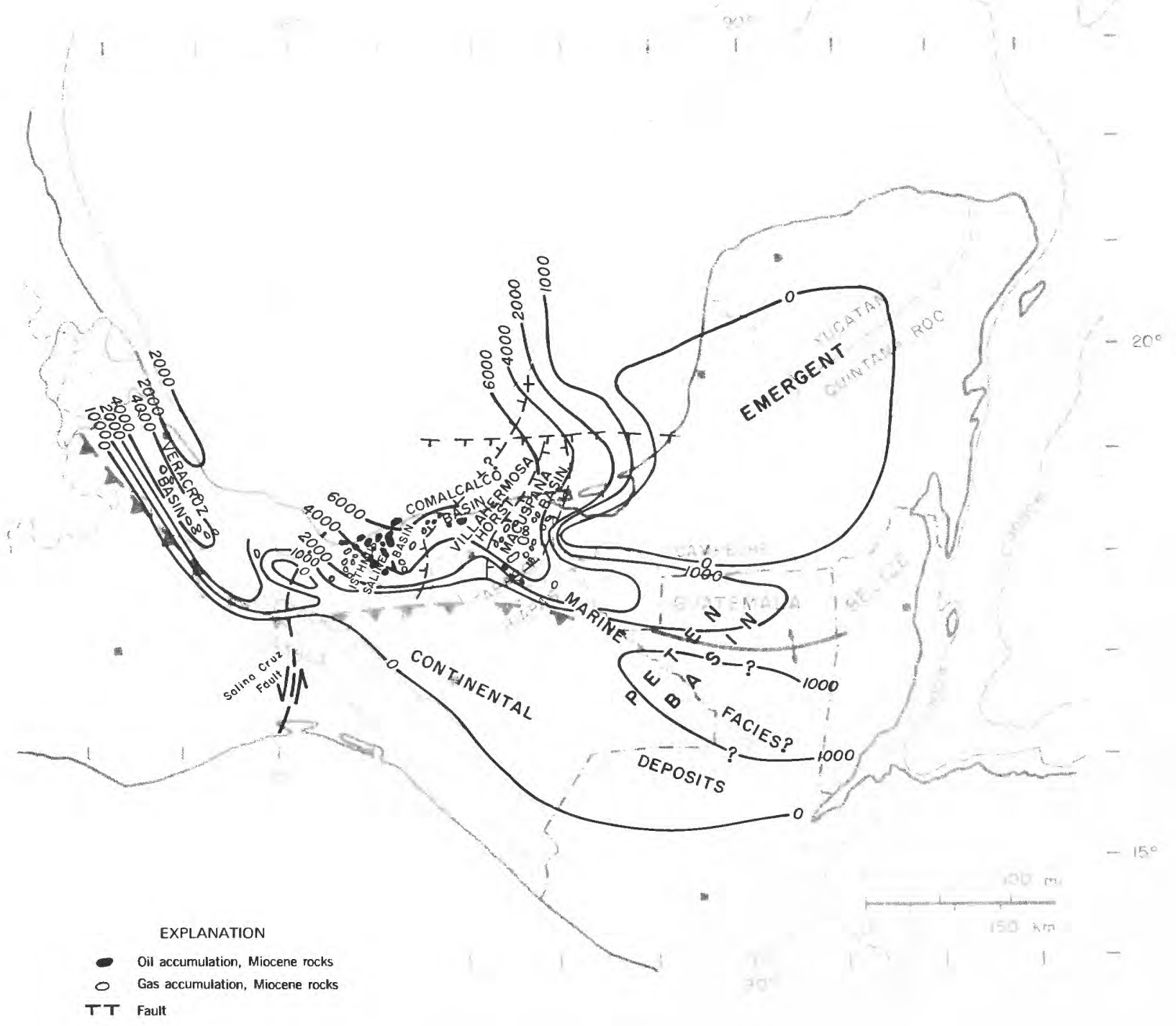

Figure 14.-Approximate thickness in meters, upper Tertiary rocks (Miocene and Pliocene), mostly restored, in Sierra Madre del Sur, Mexico, and Guatemala-Belize areas. From Castillo, 1955; Vinson, 1962; Viniegra-0., 1965, 1971, 1975a; Burkart and others, 1973; Frost and Langenheim, 1974; Mossman and Viniegra-O., 1976; Cruz-Helu and others, 1977; and LopezRamos, 1979.

7. Late Tertiary widespread epeirogenic tectonic activity, not as intense as earlier episodes, with further development of normal or strike-slip fault systems, followed by volcanism in the Sierra Madre del Sur. Strong subsidence of the Gulf Coast Tertiary basins occurred with deposition of several thousand meters of clastic sediments, mainly of Miocene age. Final growth of salt pillows and diapirs probably occurred at this time.

The pre-Pennsylvanian tectonic history of the area is poorly known. Guzman and de Cserna (1963), Lopez-Ramos (1969), Dengo and Bohnen- 
berger (1969), and Viniegra-O. (1971) postulated a Paleozoic miogeosynclinal province (Huasteca geosyncline) extending southeast across eastern Mexico and continuing eastward across Guatemala. The southwestern part of Mexico and the southern border of Guatemala are thought to have been an emergent land mass during most of pre-Pennsylvanian time, generally occupying the present belt of the Sierra Madre Occidental and Sierra Madre del Sur. Much of this miogeosynclinal province is now buried beneath a thick section of Mesozoic and Tertiary rocks. Pre-Pennsylvanian rocks are highly metamorphosed, and little is known of the Pennsylvanian and Permian sequence except for a few outcrops and well penetrations in eastern Chiapas and Guatemala. The Yucatan platform, which has a pre-Mesozoic igneous and metamorphic basement, may have been a separate block that came to its present position sometime during late Mesozoic and Tertiary time. The subdivision of southeastern Mexico and Guatemala into tectonic provinces is difficult due to overlapping tectonic patterns, differences in tectonic history, and lack of data in some areas. Agreement and consistency are not found in the literature, but the area in general can be subdivided into about eight main structural provinces, which, in varying degrees, have relatively distinct structural styles.

\section{SIERRA MADRE DEL SUR}

The Sierra Madre del Sur province, which is an extension of the Sierra Madre Occidental of northern and central Mexico, includes the mountain ranges along the Pacific side of southern Mexico and extends eastward across southern Guatemala south of the Polochic fault zone (fig. 3). This uplifted belt is the ancestral core of northern Central America and is composed mainly of metamorphic, granitic, and volcanic rocks, as well as some remnant belts of Paleozoic and Mesozoic sedimentary rocks. During much of its geologic history, the belt was above sea level and was a major clastic source area in the Mesozoic, the Cenozoic, and probably part of the Paleozoic. In southern Chiapas, the Sierra Madre del Sur is dominated by the Chiapas Massif. In Guatemala, the volcanic ranges and plateaus and the Pacific volcanic chain occupy the southern part of the province.

\section{SIERRA MADRE ORIENTAL}

The Sierra Madre Oriental mountain chain is an extension of the main belt of early Cenozoic folding and thrust faulting in northern and east-central Mexico. It lies along the western border of the Veracruz basin, merges with the Sierra Madre de Chiapas in central Chiapas State, and continues eastward to include the ranges immediately north of the Polochic fault zone in Guatemala and Belize. The entire belt consists mainly of uplifted thick Cretaceous carbonate rocks that are tightly folded and thrust faulted toward the Gulf of Mexico. Some outcrops of upper Paleozoic rocks present in southeastern Chiapas and Guatemala and lower Tertiary clastic rocks occupy elongate northwestsoutheast troughs within the folded belt. In Chiapas, the Sierra Madre de Chiapas is separated into the southeast-trending Chiapas synclinorium, which lies just north of the Chiapas Massif (figs. 4, 5), and the Chiapas anticlinorium; the latter extends southeast across north-central Chiapas and continues eastward into central Guatemala (Chiapas-Guatemala tectonic belt). The Laramide fold and thrust belt also is cut by many normal faults and by southeast- or east-trending left-lateral transcurrent fault zones with horizontal displacements as great as several kilometers (Viniegra-O., 1971, 1981; Lopez-Ramos, 1979). The Chiapas synclinorium contains erosional remnants of thick lower Tertiary continental beds that were deposited in a narrow foredeep north of the Chiapas Massif during the Laramide tectonic cycle (fig. 5). The Chiapas anticlinorium is characterized by a complex system of high-angle thrust or reverse faults and elongate southeast-trending folds recumbent toward the northeast; the folds become wider and gentler in the northwestern part of the belt.

The Chiapas anticlinorium merges northeastward into an intermediate structural zone of less intense folding, which lies between the Yucatan platform and the Sierra Madre de Chiapas. The intermediate structural zone extends eastward into the Chapayal subbasin and the west extension of the La Libertad arch in the Peten basin. The Sierra Madre de Chiapas belt narrows toward the northwest against the Chiapas Massif and is separated from the main Sierra Madre Oriental by the left-lateral Salina Cruz fault. This fault also displaces the northwest part of the Chiapas Massif and continues northward across the isthmus near 
the boundary between the Veracruz and Isthmus Saline basins; at this point, the fault is downdropped on the west by several hundred meters (Salas, 1967).

\section{YUCATAN PLATFORM}

The Yucatan platform lies approximately between latitude 18 and $24 \mathrm{~N}$. and between longitude $861 / 2$ and $921 / 2 \mathrm{E}$. (fig. 3). It is bordered on the west, north, and east by a steep underwater escarpment that begins approximately at the 200-m (650-ft) water depth contour. The southern boundary is not well defined; some authors extend it as far south as the La Libertad arch, others to about latitude $18 \mathrm{~N}$., just north of the Guatemala border. The latter boundary appears to be near the approximate north edge of the north subbasin of the Peten basin and seems to be a more logical choice (fig. 7). The offshore eastern border of the platform is very abrupt and is probably controlled by a zone of north-trending vertical step faults downdropped to the east into the deep Yucatan Channel. The western and northern borders of the platform also may be controlled by vertical fault systems, although information about the deep subsurface in the offshore area is not available. The Campeche bank, which includes the offshore Campeche oil fields, forms the southwestern segment of the platform; it is bounded on the west by the steep-sided Campeche submarine canyon and on the south by an east-west fault zone forming the northern border of the Comalcalco and Macuspana basins. The southwestern corner of the platform is bounded by the deep Tertiary Macuspana basin. The platform border there probably is also fault controlled (Bishop, 1980), although data about the subsurface are not available.

Mesozoic rocks rest on a basement of metamorphosed Paleozoic sedimentary and igneous rocks that are structurally highest in the northeastern part of the Yucatan Peninsula. From there, the platform is tilted toward the west (fig. 6), resulting in westward thickening of the Mesozoic and Tertiary sedimentary cover from about 600 to $1,000 \mathrm{~m}(2,000$ to $3,300 \mathrm{ft})$ in northeastern Yucatan to more than $6,500 \mathrm{~m}(21,000 \mathrm{ft})$ in the offshore Campeche area on the west side of the platform (Viniegra-0., 1981). Except for the eastern border, the sedimentary cover on most of the Yucatan Peninsula is only mildly disturbed. Exceptions are a northwest-trending fault zone (the Sierra de Ticul) in the north-central part of the peninsula and a north- to northeast-trending fold and fault zone (the Sierra de Bolonchan) in central Campeche State in the southwestern part of the peninsula (fig. 3).

\section{GULF COAST TERTIARY BASINS}

The Gulf Coast Tertiary basins consist of a belt of thick Tertiary sedimentary rocks north and northeast of the Sierra Madre Oriental front and occupy the general position of the coastal plain in the States of Veracruz, Tabasco, and western Campeche (figs. 1, 3). On the basis of subsurface exploration, the coastal plain region has been subdivided into several basins, although in some places basin boundaries are not clearly defined.

\section{Veracruz Basin}

The Veracruz basin is a deep Tertiary downwarp with more than $8,500 \mathrm{~m}(28,000 \mathrm{ft})$ of Paleocene through Holocene sedimentary rocks in its southeastern part (Cruz Helu and others, 1977). The basin is bounded on the southwest by the Sierra Madre Oriental fold and thrust belt and is separated from the Tampico basin on the north by the Teziutlan Massif (Santa Ana uplift) (figs. 3, 8). The basin opens into the Gulf of Mexico basin toward the northeast and merges with the Isthmus Saline basin near the Tuxtla Massif.

The subsurface structure of the southwestern flank of the basin is dominated by a buried thrust plate of Mesozoic carbonate rocks; the plate consists of westward-dipping and closely spaced imbricate thrust sheets and tight folds (Mossman and Viniegra-O., 1976). Toward the basin center, the leading edge of the buried thrust plate is as deep as $3,500 \mathrm{~m}(11,000 \mathrm{ft})$ and is marked by a high-angle reverse fault. From there, the thrust plate is progressively overlapped southwestward by marine and nonmarine clastic beds ranging in age from Eocene to Holocene. Toward the southeast, it merges with the exposed overthrust front of the Sierra Madre Oriental. East of the buried thrust plate, a narrow grabenlike trough runs parallel to the thrust front. This trough, containing more than $6,000 \mathrm{~m}(20,000 \mathrm{ft})$ of Tertiary rocks, appears to mark the axis of the basin. To the east beyond the trough, steeply dipping faults downthrown toward the Gulf of Mexico are pre- 
sent. Many local folds also are present in the basin, some of which may be related to deep-seated salt structures or shale diapirs. Beneath the main thrust belt, Viniegra-O. (1981) postulates that major folds involving salt structures overlain by Mesozoic rocks may occur at depth beneath the buried thrust plate (fig. 8). The age of the thrust faulting is thought to be Eocene, and the main overthrust plate is cut by numerous left-lateral transcurrent vertical faults, probably also of Eocene age, which are oriented perpendicular to the thrusts (Mossman and Viniegra-O., 1976). Similar transcurrent fault zones have been observed in outcrops in the Sierra Madre Oriental on the southwestern border of the basin (Viniegra0., 1965).

\section{Isthmus Saline Basin}

The Isthmus Saline basin lies east of the Veracruz basin and is bounded on the south by the Sierra Madre Oriental and on the east by the Reforma shelf or the Villahermosa horst (figs. 2, 3). The basin extends northward offshore into the Gulf of Mexico shelf and merges to the northeast with the Comalcalco basin. Structures in the basin include many complexly block-faulted salt domes or massifs that are at shallow depths (about 100 to $1,000 \mathrm{~m}$ or 325 to $3,250 \mathrm{ft}$ ) in the western part of the basin and are deeper and more widely spaced in the eastern part. Most salt structures are relatively broad, high-relief features with salt rise on the order of 1,000 to $3,000 \mathrm{~m}(3,300$ to $10,000 \mathrm{ft})$ to as much as $5,000 \mathrm{~m}(16,000 \mathrm{ft})$. Piercement structures are common in the western part of the basin; in some cases, rocks as old as Eocene, Cretaceous, or Jurassic have been brought to shallow depths or are exposed at the surface. The age of salt uplift is unknown; estimates in the literature range from Laramide (Late Cretaceous-early Tertiary) to Miocene.

\section{Comalcalco Basin}

The Comalcalco basin is an area of thick Tertiary sedimentary rocks oriented northeast-southwest along the Gulf coastal plain and extending into the offshore area north of the Reforma shelf (fig. 3). To the west, it merges with the Isthmus Saline basin and to the northeast with the northern extension of the Macuspana basin. The northern limit may be defined by an east-trending fault zone marking the southern boundary of the Campeche shelf. Numerous anticlines or domes are present that may be related to deep-seated salt structures. The basin contains a great thickness of Tertiary rocks; minimum depth to the Cretaceous is about 6,000 to $7,000 \mathrm{~m}(20,000$ to $23,000 \mathrm{ft})$.

\section{Macuspana Basin}

The Macuspana basin is bounded on the west by the Villahermosa horst and extends offshore to the north where it apparently merges with the eastern extension of the Comalcalco basin (figs. 2, 3 ). The southern and eastern boundaries are not well defined. The basin appears to terminate at the northern boundary of the Sierra Madre de Chiapas. Eastward, it may merge with the southwestern corner of the Yucatan platform, although Acevedo and Dautt (1980) indicate that the eastern border is a northeast-trending fault zone. Some evidence suggests that the thick Tertiary section defining the basin may extend eastward or southeastward into the northern segment of the Peten basin in Guatemala (figs. 7, 13, 14). Numerous domal and anticlinal structures are present in the Macuspana basin and may represent deep-seated salt structures, although salt has not been penetrated by wells except in the extreme southern part of the basin. These structures generally are oriented northeast-southwest in the northern part of the basin and more easterly in its southern part.

\section{REFORMA SHELF}

The Reforma shelf (Jalpa Anticlinorium of Viniegra-O., 1981), which includes the main Mesozoic productive area in northwestern Chiapas and southwestern Tabasco, occupies the southern part of the Villahermosa horst. This feature is a northnortheast-trending block oriented roughly parallel with the west coast of the Yucatan Peninsula (figs. $2,3,5)$. The general structure of the horst block is that of a shelf tilted toward the north and west and cut by numerous northwest-trending steeply dipping normal faults. These form a system of horst and graben structures, which are accentuated by closely faulted salt swells and are down stepped to the north into the Comalcalco basin (fig. 5). The detailed structural pattern is very complex, as the rocks also are cut by southwestdipping reverse faults and by northwest-trending wrench faults with left-lateral displacements 
(Acevedo and Dautt, 1980; Viniegra-0., 1981). The Reforma shelf, which lies immediately north of the Sierra Madre front, makes up the southern part of the Villahermosa horst and is interpreted by Viniegra-O. (1981) to be the downfaulted northwesterly plunging nose of the Chiapas anticlinorium. It may be related to the system of northwest-oriented left-lateral wrench faults identified in surface mapping in the Sierra Madre de Chiapas (Viniegra-0., 1971, 1981; Lopez-Ramos, 1979), which have also been identified in the Reforma subsurface. Left-lateral movement on the wrench faults during the orogeny may have offset the Mesozoic carbonate-bank sequence northwesterly in the Reforma area. Concurrent sediment loading and downwarping north of the rising Sierra Madre de Chiapas resulted in salt movements that produced the horsts and grabens of the Villahermosa horst. The Villahermosa horst underwent relatively continuous growth throughout the Tertiary, perhaps in part a consequence of great sediment loading and downwarping in the Tertiary Macuspana, Comalcalco, and Isthmus Saline basins. In contrast, Tertiary rocks are considerably thinner in the Reforma area than they are in the basin areas on its west, north, and east flanks.

\section{CAMPECHE SHELF}

The offshore Campeche area of recently discovered giant oil fields is referred to by Viniegra-O. (1981) as the "Campeche shelf." The exact boundaries of this province are not yet known; it lies along the western border of the Yucatan platform and is bounded on the south by an east-trending zone of normal and possibly strike-slip faults downdropped to the south (figs. 3, 6). On the west, the shelf drops abruptly into the Campeche submarine canyon at about the $200-\mathrm{m}$ (650-ft) water depth, and on the north it merges with the main scarp of the platform border. The overall structure is that of a shelf tilted toward the west and cut by north-trending normal faults that form a system of horsts and grabens accentuated by salt pillows similar to those on the Reforma shelf. The detailed structure on the productive section is similar to that at Reforma; it is complicated by severe faulting and fracturing due to salt movement, as well as by numerous southwest-dipping reverse faults and some left-lateral wrench faults.

\section{OFFSHORE SALT STRUCTURE PROVINCE}

The main offshore salt structure province in the Gulf of Campeche is a complex of salt domes, ridges, and large salt massifs mobilized mainly by sediment loading (Martin, 1980). Salt structures in the onshore coastal plain province along the south border of the Gulf of Campeche are much smaller in diameter and are mainly high-relief domes and anticlines. Mobilization of the salt may have been initiated as early as the Late Cretaceous by sediment overburden (Contreras and Castillon, 1968; Salas, 1967; Bishop, 1980) or by combined overburden and Laramide compressive stresses directed from the southwest (Viniegra-O., 1981). Salt uplift must have continued during deposition of the thick clastic sequence of Paleocene, Eocene, and Oligocene ages in the coastal plain area but may have been near completion some time during the Miocene, as suggested by the presence of Miocene beds, although thinned, over most of the domal structures. Some authors, however, propose that salt structure growth continued from late Mesozoic through late Tertiary time (Ladd and others, 1976; Martin, 1980).

\section{PETEN BASIN}

The Peten basin lies south of the Yucatan platform, occupying most of northern Guatemala and part of the State of Chiapas, Mexico (figs. 3, 7). Its southern boundary is the east-trending Polochic fault zone. The northern limit is uncertain because of lack of subsurface control, but its eastern limit is reasonably well defined by the Maya Mountains block in Belize although to the south the basin opens eastward into the Caribbean through the Sartsun portal. On the west, the basin province merges with the Chiapas anticlinorium and the adjacent intermediate structural province to the north. The Peten basin is divided by the east-trending La Libertad arch into a northern segment (the "north basin") and a larger southern segment designated as the Chapayal basin by some authors. Subsurface control is lacking, but some evidence indicates that the north subbasin may open westward into the southern part of the Macuspana basin, perhaps through an east-west grabenlike trough. The La Libertad arch dominates the internal structure of the basin, but several large subsidiary folds in the main basin areas and salt pillows or piercement domes in the south segment also are reported (Bishop, 
1980). Some evidence indicates that salt of Early Cretaceous or Jurassic age may lie at depth in the north basin area and that salt structures also may be present (Lopez-Ramos, 1973).

\section{Petroleum GeOlogy}

\section{INTRODUCTION}

Early interest in the petroleum possibilities of southern Mexico was stimulated by the presence of numerous oil seeps in the State of Tabasco and other parts of the Isthmus of Tehuantepec. Oil was first discovered in 1904 at the San Cristobal field in eastern Veracruz State in the southwestern part of what is now known as the Isthmus Saline basin. Exploration subsequently spread through much of the southeastern Mexico coastal plain, and by the late 1960 's about 80 fields had been discovered, almost all producing from Miocene sandstone reservoirs (the Encanto, Concepcion, and Amate Formations) in the Isthmus Saline and Macuspana basins (fig. 2). Most of these fields are on salt structures or on anticlines and domes that may be related to deep-seated salt structures.

The possibilities for Mesozoic oil in southeastern Mexico had long been considered by Pemex geologists (Guzman and others, 1955; LopezRamos, 1979; Viniegra-O., 1971, 1981). Abundant oil seeps were known along the front of the Sierra Madre de Chiapas, and in 1960 oil was found in Lower Cretaceous dolomite reservoirs at the Cerro de Nachital field (later abandoned), located in the southern part of the Isthmus Saline basin near the Sierra Madre de Chiapas front (fig. 2). Active exploration for Mesozoic oil in the southeastern Mexico area began during the 1960's and resulted in drilling of several wells in the Sierra Madre de Chiapas province and on the Yucatan Peninsula. None of these wells was productive from Mesozoic rocks, but the stratigraphic information gained from the drill holes led to the identification of Cretaceous reef and backreef facies, similar to those present in the Tampico basinGolden Lane area. An active geophysical exploration program was then undertaken to the north in the coastal plain area, which resulted in the mapping of several deep seismic structures near Villahermosa, Tabasco State. Subsequent drilling there led to the discovery in 1972 of the Sitio
Grande and Cactus oil fields, producing from Cretaceous carbonate reservoirs of the Sierra Madre Limestone (Acevedo and Dautt, 1980; ViniegraO., 1981).

The Reforma discoveries were followed by discoveries in the offshore Campeche area, which had been explored by extensive marine seismic surveys that identified a large number of structures on the offshore Campeche shelf. Chac No. 1, the discovery well in 1976, produced $20^{\circ}$ API (American Petroleum Institute) oil from a Paleocene dolomite breccia reservoir and bottomed in Jurassic (Oxfordian) carbonate and shale beds.

\section{TERTIARY CLASTIC DEPOSITS}

Of the approximately 80 fields that have been found in Tertiary clastic reservoirs in southeastern Mexico, about 50 are oil, or oil and gas, and 30 are gas or gas-condensate fields (figs. $2,13,14$ ).

\section{ISTHMUS SALINE AND COMALCALCO BASINS}

Fields in the Tertiary Isthmus Saline and Comalcalco basins are oil or combination oil and gas fields. Most of the oil production is from Miocene sandstone and siltstone reservoirs of the Encanto and Concepcion Formations on salt structures (fig. 4). Most of these fields are small to medium in size, but several are classed as giants (Acevedo and Dautt, 1980). All large fields are associated with diapiric salt structures, which are complexly block faulted by salt intrusion (figs. 15, 16).

\section{MACUSPANA BASIN}

Most of the Tertiary gas and gas-condensate fields are in the Macuspana basin; all are located on block-faulted domes or anticlines, some of which may be related to deep-seated salt intrusion, although salt has not been penetrated in the basin except in shallower structures in its southern part. Almost all production is from lower Miocene sandstone bodies of the Amate Formation (fig. 4). Some gas also is produced from middle Miocene sandstones of the Zargazal and Encajonada Formations. Three giant gas and gascondensate fields are located in this basin: Jose Colomo (about 3 to $4 \mathrm{Tcf}$ ), Chilapilla (fig. 16), and Hormiguero (Acevedo and Dautt, 1980). Small amounts of oil are produced from Miocene reservoirs in the southern part of the basin. 
Of the 8 to 10 small Tertiary gas fields in the Veracruz basin, most produce from sandstone and conglomerate reservoirs of Miocene age near the basin center (Encanto and Concepcion Formations). The productive Miocene reservoirs occur in a conglomerate, sandstone, and shale sequence about $1,000 \mathrm{~m}(3,300 \mathrm{ft})$ thick deposited in a deepwater environment (Cruz Helu and others, 1977). Conglomerate beds are composed of coarse fragments of Cretaceous limestone with some metamorphic and igneous material derived from the uplifted Sierra Madre province to the west. A similar deepwater turbidite facies occurs in the Oligocene and Eocene sequence but is located farther west, closer to the basin border. Some minor production and noncommercial gas shows have also been encountered in these older beds. Average porosity of the Miocene reservoirs is about 6 to 8 percent. The matrix is generally shaly, and permeabilities are not high, but some sandstone beds are as thick as $100 \mathrm{~m}$ (350 ft). Exploration success in Tertiary reservoirs in this basin thus far has been disappointing, but the basin is not heavily drilled and is structurally complex. The possibilities for finding large stratigraphic traps may be good (Cruz-Helu and others, 1977).

\section{RESERVOIRS}

Miocene reservoirs are primarily discontinuous, regressive-marine, nearshore sandstone and siltstone bodies interbedded and intertongued with marine and brackish-water shale; some carbonaceous and lignitic beds occur in the upper part of the oil-bearing strata (figs. 4, 8). The total Miocene section is at least $5,000 \mathrm{~m}(16,000 \mathrm{ft})$ thick in parts of the Isthmus Saline, Comalcalco, and Macuspana basins but is much thinner over salt structures, which probably were growing at this time. Sandstone beds vary greatly in thickness, but some are very thick. Porosities and permeabilities range widely, but porosity values of $\mathbf{1 5}$ to 25 percent and intermediate permeability values are commonly reported. In the Jose Colomo field, producing reservoirs of the lower part of the Amate Formation are exceptionally thick, about $200 \mathrm{~m}(650 \mathrm{ft})$, and porosity values of 10 to 30 percent are reported. Reserves of this field were reported in 1963 to be about 2.75 Tcf (Beebe, 1968).
Sandstone and conglomerate bodies interbedded with shale occur in the Paleocene, Eocene, and Oligocene sequence in the southern part of the Isthmus Saline basin and in outcrops along the Sierra Madre front. To date, no important production has occurred in these beds, although oil seeps in outcrops and some shows in wells are reported (Guzman and others, 1955). In some cases, these beds are tightly cemented and of low porosity. In the basin area, much of this sequence was deposited under deepwater conditions, and most coarse-clastic beds probably are turbidite deposits. Few wells within the Isthmus Saline and Macuspana basins have penetrated these beds; in most cases, they probably are deeply buried in low areas between salt structures but should provide deeper prospects for flank accumulations ondiapiric structures. The sequence becomes more limy toward the east, where reservoir quality is diminished (fig. 13) ${ }^{1}$.

\section{SOURCE ROCKS}

Source rocks for most oil and gas in the Tertiary clastic sequence of southeastern Mexico are considered to be shales of the marine and lagoonal Miocene sequence associated with the reservoir sands (Guzman and others, 1955; Guzman and de Cserna, 1963). However, most of the Isthmus Saline basin fields contain oil or combination oil and gas accumulations, whereas the Macuspana basin fields are gas or gas-condensate fields. This raises the question of possible differences in source rocks. The Isthmus Saline basin fields are associated . with complexly faulted diapiric salt structures, whereas the Macuspana basin gas fields are on nondiapiric domes and anticlines. These relations suggest the possibility that the oil deposits in the Isthmus Saline basin fields may not be derived entirely from Tertiary source rocks but may include in part oil that migrated upward from underlying Upper Jurassic or Cretaceous basinal source rock facies into Tertiary reservoir beds on the complexly faulted salt structures.

\section{REGIONAL CAP ROCKS}

The thick Tertiary shale sequence interbedded with sandstone reservoir facies provides an effective seal for both structural and stratigraphic ac-

'From Guzman and others, 1955; Contreras and Costillo, 1968; Lopez-Ramos, 1979; Acevedo and Dautt, 1980. 


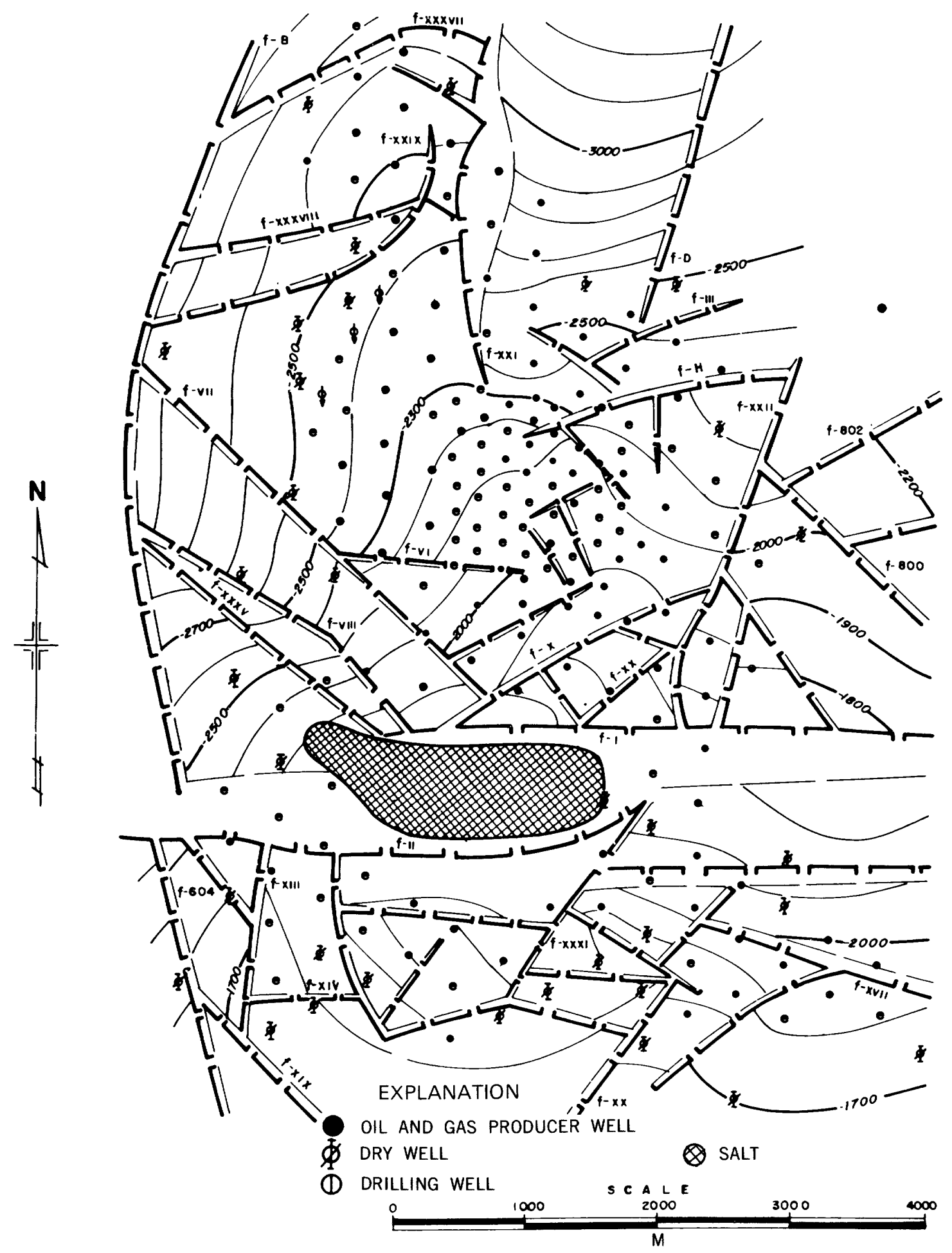

Figure 15.-Structure (depth in meters) of top of Encanto Formation (Miocene), Cinco Presidentes oil field. Location of field, lat. $18^{\circ} 11^{\prime} 30^{\prime \prime}$ N., long. $94^{\circ} 00^{\prime} 30^{\prime \prime}$ W. (After Acevedo and Dautt, 1980.) 


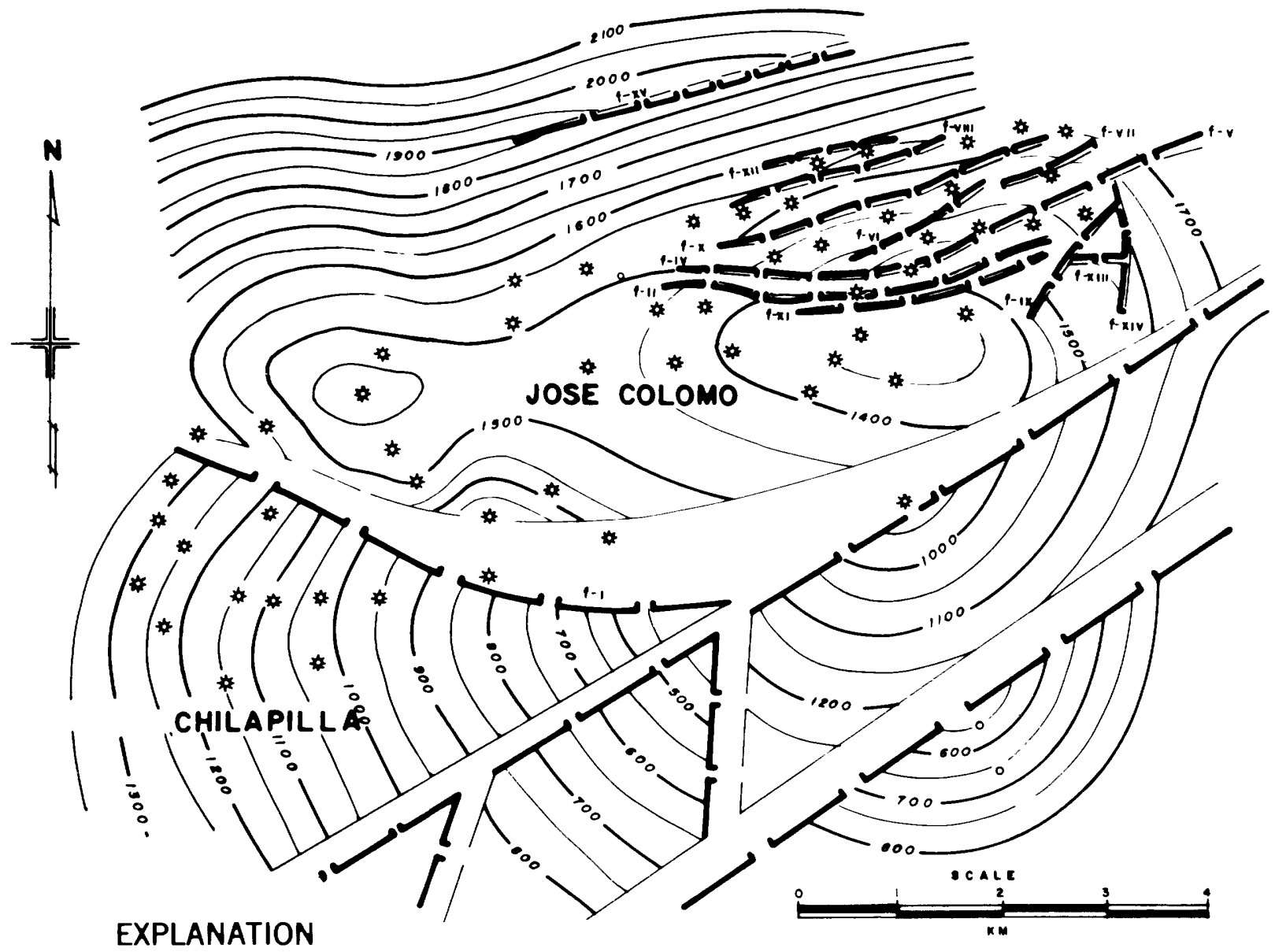

姑 GAS PRODUCER WELL

O DRY WELL

Figure 16.-Structure (depth in meters) of top of Amate Formation (Miocene), Jose Colomo-Chilapilla gas field, Macuspana basin. Location of field, lat. $17^{\circ} 58^{\prime}$ N., long. $92^{\circ} 28^{\prime}$ W. (After Acevedo and Dautt, 1980.)

cumulation throughout most of the Tertiary basin province. Diapiric salt masses should be good updip seals for Tertiary sandstone reservoirs on the flanks of piercement structures, where fractured reservoirs are also important.

\section{TRAPS}

Most traps in known Tertiary accumulations are structural, either anticlinal or domal folds or fault traps associated with salt structures. However, distribution patterns and thickness of clastic reservoir facies are also important in determining reserves and production characteristics on indi- vidual structures; some good structures have not yet proven productive. The discontinuous nature of the Tertiary sand bodies implies that stratigraphic trapping may be important to future discoveries. A stratigraphic exploration program has not yet been undertaken.

\section{ANALOGS}

Probably the best stratigraphic and structural analog for the southeastern Mexico Tertiary basin productive province is the Gulf Coast Tertiary basin of the United States, where many fields are related to similar reservoir, trap, and source rock conditions. 
The great petroleum potential of southeastern Mexico and Guatemala is directly related to deposition of the "Great Carbonate Bank of Yucatan" (Viniegra-O., 1981), the thick sequence of reef and bank carbonate and evaporite beds of Late Jurassic (Oxfordian) through early Tertiary age (figs. 11, 12). The bank complex, which is present on the Yucatan platform, in Guatemala, throughout the Sierra Madre Oriental and Sierra Madre de Chiapas, and part of the subsurface to the north, is generally from 1,000 to $2,000 \mathrm{~m}(3,300$ to 6,600 $\mathrm{ft}$ ) thick and reaches thicknesses of more than $3,000 \mathrm{~m}(10,000 \mathrm{ft})$ in Yucatan, Guatemala, and Chiapas.

\section{REFORMA SHELF}

After the 1972 discoveries of the Cactus and Sitio Grande oil fields, intensified exploration and development drilling during the next few years resulted in several other significant discoveries and elevated the Reforma area to Mexico's leading oil province. As of January 1981, 36 fields had been discovered, most producing from "middle" and Upper Cretaceous and Upper Jurassic carbonate reservoirs (figs. 2,17 , tables 2,3 ) at depths between 4,000 and $6,000 \mathrm{~m}(13,000$ and $20,000 \mathrm{ft})$ (World Oil, 1981). Minor production in some of the fields is from Tertiary sandstones. Approximately 75 to 100 onshore structures are yet to be tested (World Oil, 1980). The new fields are located on the Reforma shelf, a segment of the Villahermosa horst, which separates the Isthmus Saline and Macuspana Tertiary basins. Production in the Mesozoic Reforma fields is primarily from a reef bank-edge dolomitized detrital carbonate facies (the Tamabra facies) on salt pillow or salt swell structures that have caused intense microfracturing of the dolomite reservoirs (figs. 5, 12). Depths to the top of the reservoir section range from 3,800 to $4,500 \mathrm{~m}(12,000$ to $15,000 \mathrm{ft})$. Regional cap rocks for these fields are Tertiary shales and to a lesser extent Cretaceous shales. The producing column is unusually thick in many of the fields, averaging more than $300 \mathrm{~m}(1,000 \mathrm{ft})$ and ranging as high as $900 \mathrm{~m}(3,000 \mathrm{ft})$ or more at the Sitio Grande field (fig. 5). Matrix porosity averages about 8 to 10 percent, but effective porosity is considerably higher because of intense microfracturing. Permeability values are very high, ranging up to as much as $\mathbf{8 , 0 0 0} \mathrm{mD}$ (Acevedo and Dautt,
1980). Average production rates are reported to be 3,000 to $5,000 \mathrm{bbl} / \mathrm{d}$; some are as much as 10,000 to $20,000 \mathrm{bbl} / \mathrm{d}$. Gravity of the oils ranges from $25^{\circ}$ to $45^{\circ}$ API; gas-oil ratios are about 1,500:1. The main source beds for the Mesozoic oils in the Reforma area are organic-rich black shale and shaly limestone beds of Late Jurassic (Kimmeridgian and Tithonian) age (Viniegra, 1971, 1981). Dark-colored, shaly rocks in the Lower and "middle" Cretaceous section may also be the source of some of the oil. As of January 1981, 185 wells were producing $953,394 \mathrm{bbl} / \mathrm{d}$ of oil, 133,216 bbl/d of condensate, and $2.038 \mathrm{Bcf} / \mathrm{d}$ (billion cubic feet per day) of gas (World Oil, 1981). The largest of the Mesozoic fields is the A. J. Bermudez complex (fig. 18), reported as about $8 \mathrm{BBOE}$ ultimate recoverable reserves (Acevedo and Dautt, 1980).

\section{CAMPECHE SHELF}

Since 1976, about 15 major fields have been discovered on the Campeche shelf, some of which have now been combined into single-field complexes (figs. 2, 6, 19; tables 2, 3). All fields are located on sharply defined and complexly faulted structural domes or anticlines with exceptionally large closures, associated with salt pillows or domes. In most cases, oil columns are very large ( 50 to $>500 \mathrm{~m}$ or 160 to $>1,600 \mathrm{ft}$ ), and reservoirs are intensely microfractured dolomites of Paleocene and Cretaceous age. Oil saturation is also reported in Uppe Jurassic sandstones at some of the wells. The stratigraphic section penetrated thus far includes carbonate and clastic rocks of Late Jurassic age, carbonate rocks of Cretaceous and Paleocene age, Eocene carbonate rocks and evaporite deposits, and post-Eocene marls. Bank carbonate beds have been identified in the Jurassic, Cretaceous, Paleocene, and upper Eocene sections. Heavy dolomitization of the carbonate rocks has hampered precise age identification by Pemex geologists, but parts or all of the Cretaceous section apparently are absent in some wells. The major production thus far has been from dolomitized forereef talus (Tamabra) facies, similar to that at Reforma.

The source rocks for the oil in the offshore Campeche province are believed to be the same as those of the Reforma area, primarily post-Oxfordian Jurassic organic-rich black shale and carbonate beds and secondarily Lower Cretaceous dark 
EXPLANATION

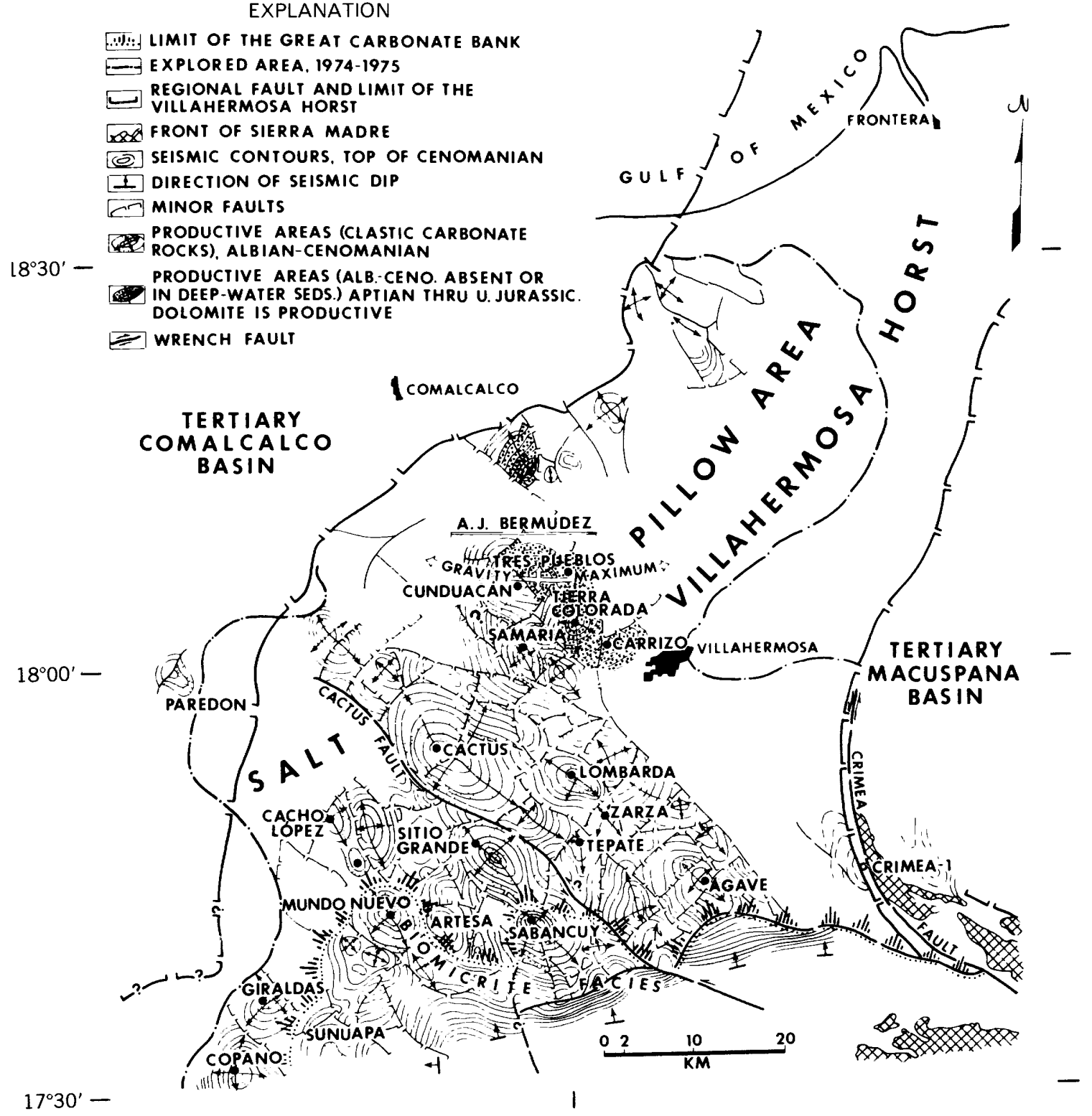

Figure 17.-Seismic structural map, Reforma area Chiapas-Tabasco States, top of Cretaceous Cenomanian. (After Viniegra-0., 1981.)

shale and shaly limestone beds. The proximity of the Jurassic source rock section is believed to be a principal requisite for major oil accumulations in all parts of the section, including those in the Cretaceous and Paleocene reservoirs. Cap rocks for the fields appear to be upper Paleocene shales.

The largest accumulation is in the Cantarell complex (figs. 6, 19, 20, 21), which includes the Chac, Akal, and Nohoch fields, reportedly contain- ing from 8 to $10 \mathrm{BB}$ of ultimate recoverable proven reserves (Acevedo and Dautt, 1980; World Oil, 1981). The effective oil column at this complex averages about $800 \mathrm{~m}(2,600 \mathrm{ft})$; the thickest encountered so far is about $1,000 \mathrm{~m}(3,300 \mathrm{ft})$ at the Nohoch No. 2 well. The combined Abkatun, Kanaab, Taratunich, and Ixtoc structures are predicted to become a second giant complex as drilling progresses (Acevedo and Dautt, 1980). 


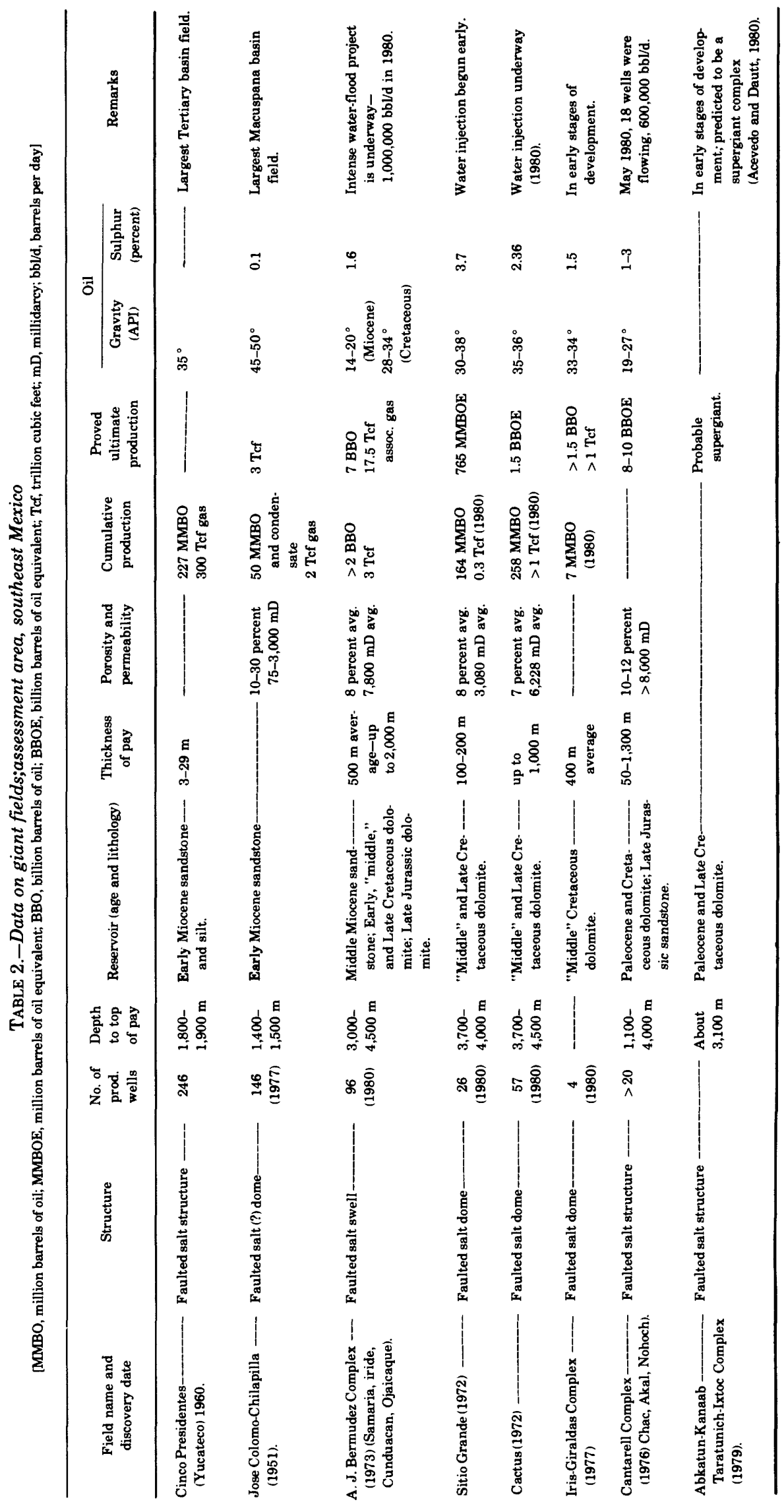


TABLE 3.-Generalized stratigraphic columns in Reforma area and offshore Campeche area

\begin{tabular}{|c|c|c|c|c|}
\hline \multirow[b]{2}{*}{ Unit } & \multicolumn{2}{|r|}{ Reforma area } & \multicolumn{2}{|r|}{ Offshore Campeche area } \\
\hline & Thickness & Lithology & Thickness & Lithology \\
\hline Eocene ----- & $400-800 \mathrm{~m}$ & $\begin{array}{l}\text { Offshore marine shale with thin } \\
\text { beds of sandstone. }\end{array}$ & $95-170 \mathrm{~m}$ & $\begin{array}{l}\text { Marine green-gray bentonitic } \\
\text { shale, some bank carbonate } \\
\text { upper part. }\end{array}$ \\
\hline $\begin{array}{l}\text { Upper ---_-- } \\
\text { Cretaceous. }\end{array}$ & $70-400 \mathrm{~m}$ & $\begin{array}{l}\text { Marine marl, fine-grained argil- } \\
\text { laceous limestone and thin } \\
\text { shale beds; x'line and fine- } \\
\text { grained limestone and chert } \\
\text { in lower part. }\end{array}$ & & \\
\hline $\begin{array}{l}\text { Middle -- } \\
\text { Cretaceous. }\end{array}$ & $\begin{array}{l}\text { 120-700 m } \\
\text { (Aptian- } \\
\text { Cenomanian } \\
\text { absent in } \\
\text { Northern part } \\
\text { of area). }\end{array}$ & $\begin{array}{l}\text { Marine platform and basin dolo- } \\
\text { mite and dolomitic limestone, } \\
\text { vuggy, with porous dolomitic } \\
\text { breccias and fractures; some } \\
\text { black chert beds. }\end{array}$ & $\begin{array}{l}\text { is about } 425 \mathrm{~m} \\
\text { (irregularly } \\
\text { absent in parts } \\
\text { of the offshore } \\
\text { productive } \\
\text { area). }\end{array}$ & $\begin{array}{l}\text { Identification of Cretaceous sub- } \\
\text { divisions is difficult because of } \\
\text { dolomitization and intense mi- } \\
\text { crofracturing; lithology is x'line } \\
\text { dolomite with fractures and } \\
\text { dissolution cavities. }\end{array}$ \\
\hline $\begin{array}{l}\text { Upper --_-_- } \\
\text { Jurassic. }\end{array}$ & $800-1,600 \mathrm{~m}$ & $\begin{array}{l}\text { Marine platform dark gray } \\
\text { oolitic, pelletal, and bioclastic } \\
\text { limestone, in part dolomitized, } \\
\text { with anhydrite and shale beds } \\
\text { and much dark brown and gray } \\
\text { shale. }\end{array}$ & $\begin{array}{l}\text { Tithonian }=>81 \\
\text { m } \\
\text { Kimmeridgian }= \\
>160 \mathrm{~m} \\
\text { Oxfordian }= \\
>280 \mathrm{~m}\end{array}$ & $\begin{array}{l}\text { Argillaceous limestone, shale, } \\
\text { and some sandstone. } \\
\text { Oolitic limestone, shale, and do- } \\
\text { lomite with some anhydrite } \\
\text { beds. } \\
\text { Dark gray shale, red-brown silt- } \\
\text { stone, and argillaceous, partly } \\
\text { oolitic limestone and sandstone; } \\
\text { some dolomite and anhydrite; } \\
\text { complete section not penetrated. }\end{array}$ \\
\hline $\begin{array}{l}\text { Pre-Upper---- } \\
\text { Jurrasic and } \\
\text { Triassic. }\end{array}$ & ?(not penetrated) & Red beds, salt, and anhydrite? & ?(not penetrated) & $\begin{array}{l}\text { Red beds, salt, and anhydrite, } \\
\text { grading to red beds to east? }\end{array}$ \\
\hline $\begin{array}{l}\text { Upper - } \\
\text { Paleozoic? }\end{array}$ & ?(not penetrated) & $\begin{array}{l}\text { Metamorphosed marine carbon- } \\
\text { ate, shale, and sandstone? }\end{array}$ & ?(not penetrated) & $\begin{array}{l}\text { Metamorphosed marine carbon- } \\
\text { ate shale and sandstone? Pos- } \\
\text { sibly some intrusive igneous } \\
\text { bodies? }\end{array}$ \\
\hline
\end{tabular}




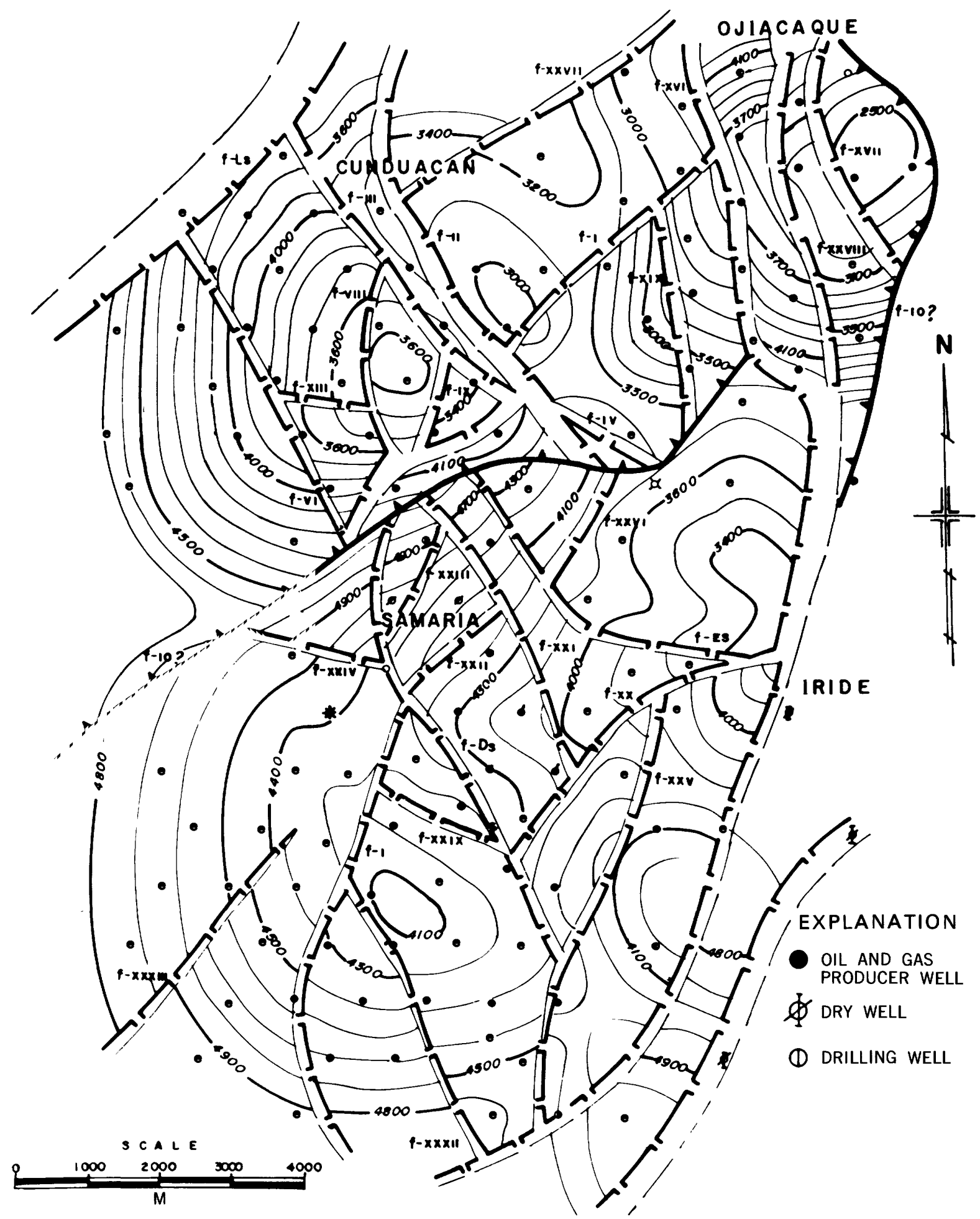

FIGURE 18.-Structure (depth in meters), top of Upper Cretaceous, A. J. Bermudez Complex oil field, Reforma area. Location of field at lat $18^{\circ} \mathrm{N}$., long $93^{\circ} 06^{\prime}$ W. (After Acevedo and Dautt, 1980.) 


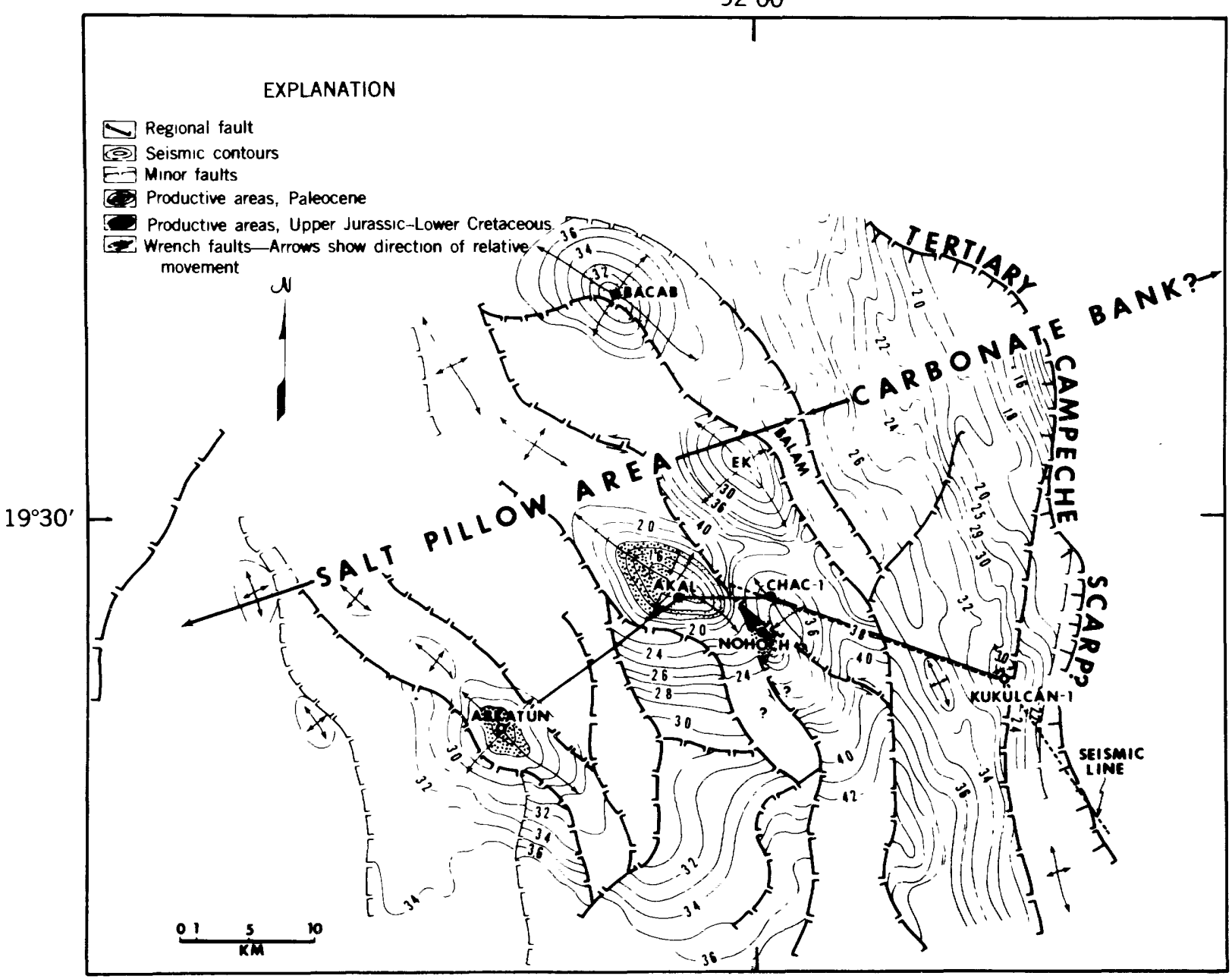

Figure 19.- Seismic structural map, offshore Campeche area, top of lower Paleocene. (After Viniegra-O., 1981.)

Some of the oils are relatively low gravity $\left(20^{\circ}\right.$ API), particularly in the Cantarell complex, but lighter oils $\left(30^{\circ}\right.$ to $\left.33^{\circ} \mathrm{API}\right)$ were found in some of the more recently discovered fields (Abkatun, Kanaab, Ku, and Ixtoc) (Acevedo and Dautt, 1980). Matrix porosity in most of the fields averages somewhat higher than that at Reforma. Because of intense microfracturing caused by salt movement, permeability values are exceptionally high and are somewhat greater than those recorded at Reforma (Viniegra-O., 1981). Initial production rates are some of the highest ever encountered $(30,000 \mathrm{bbl} / \mathrm{d}$ at Ixtoc and 50,000 to 60,000 bbl/d at some Cantarell complex wells). As of July 1980,20 wells were on production at an average per well rate of $32,700 \mathrm{bbl} / \mathrm{d}$ (World Oil, 1981).

Geophysical surveys have identified more than 200 structures in the offshore area. About 20 had been drilled by early 1981,5 of which were nonproductive. Of these 200 known offshore structures, Pemex estimates that 60 eventually will be productive (World Oil, 1981).

\section{RUBELSANTO AREA (GUATEMALA)}

The central and northern Guatemala and Belize area occupies the distal portion of the early Mesozoic evaporite trough, which extends southeastward from the southwestern Gulf of Mexico (figs. 3, 9). The Cretaceous reef or bank-edge belt that passes through the Reforma-Campeche area and around the offshore periphery of the Yucatan platform (fig. 12) may continue southward across Belize and possibly into south central Guatemala (Viniegra-O., 1971, 1975b, 1981; Garcia, 1978). Interest in exploring this reef belt began some time 


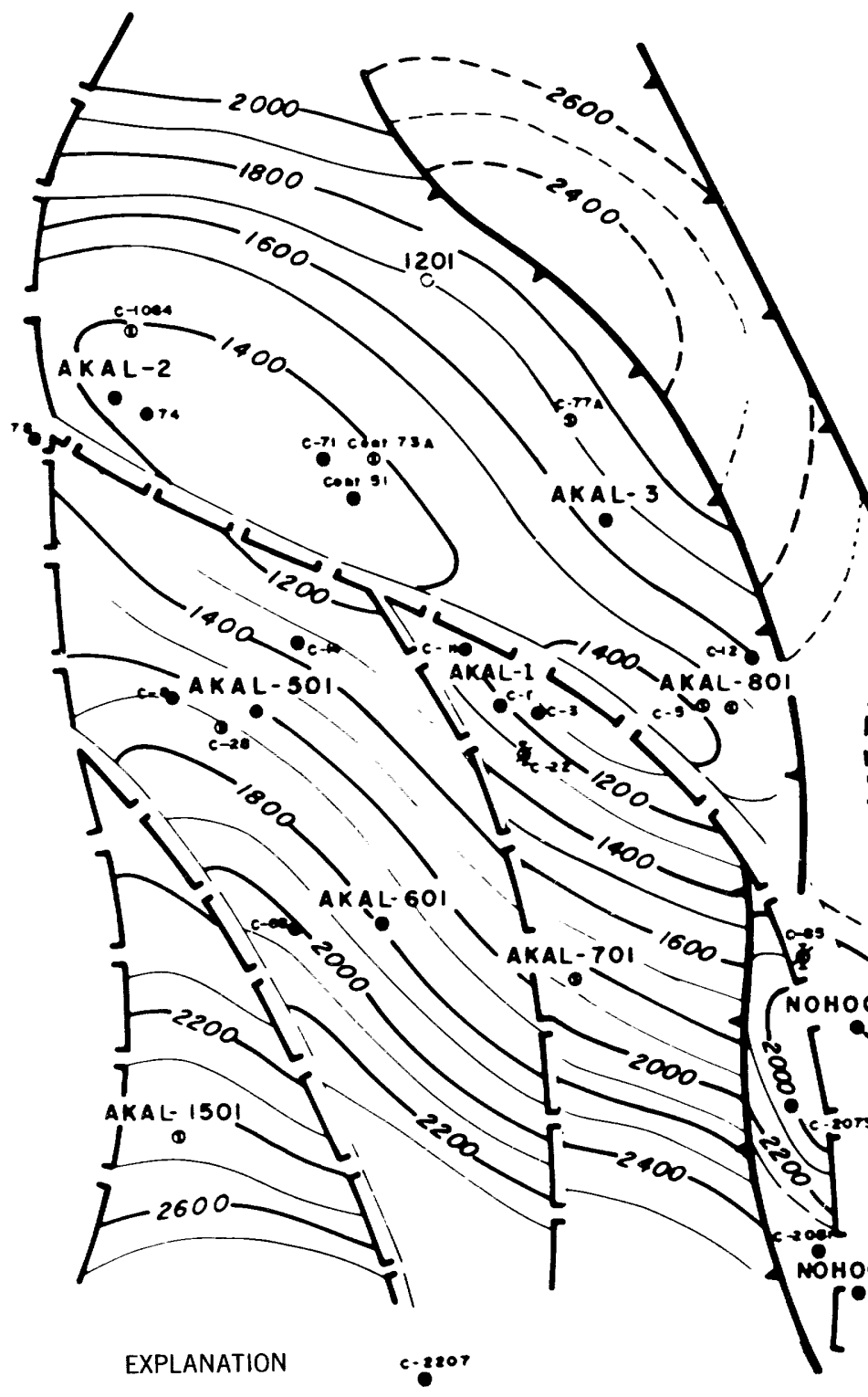

Oil and gas producer well

$\Varangle$ Dry well

(1) Drilling well
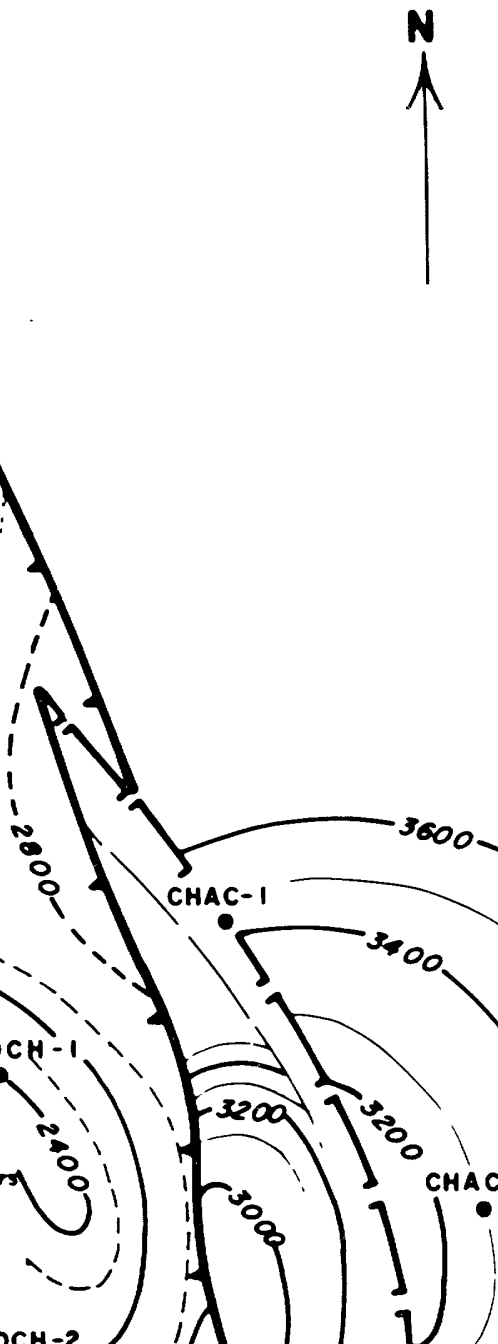

act-2
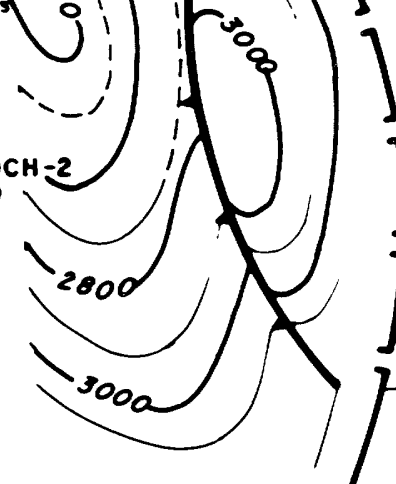


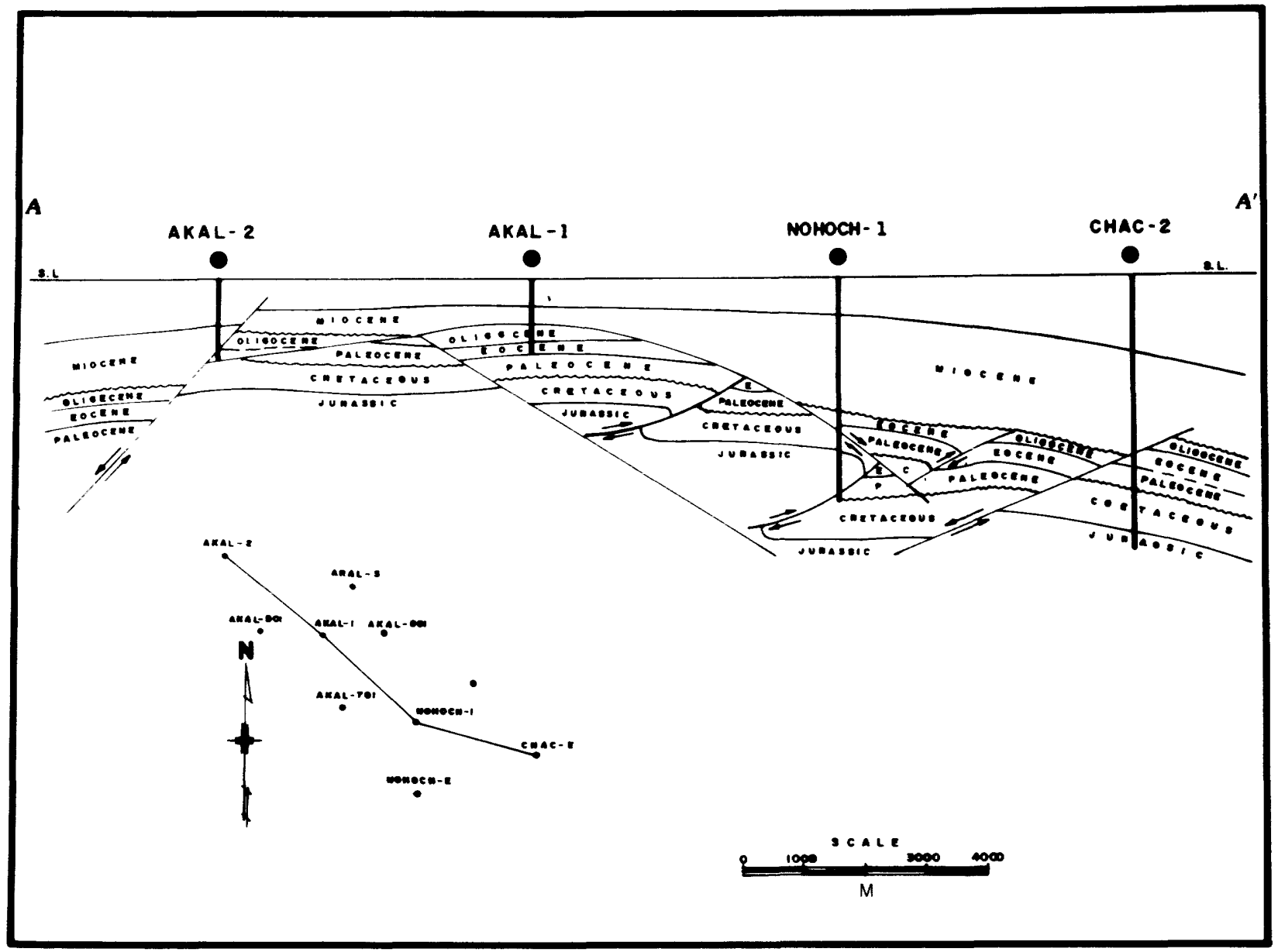

Figure 21.-Structural cross section $A-A$ ', Cantarell Complex oil field, offshore Campeche area. (After Acevedo and Dautt, 1980.)

ago when numerous wells were drilled in onshore and offshore Belize. None of these were productive, and the earlier wells drilled in Guatemala also were disappointing. In 1974, oil was discovered at Rubelsanto in west-central Guatemala, and three other fields since have been found in the vicinity of Rubelsanto (figs. 2, 7). All are apparently on salt structures and produce from the "middle" Cretaceous carbonate and evaporite section. The total recoverable reserves of these fields are small-about 50 MMB (World Oil, 1981). Recently, a significant discovery was announced in the northwestern corner of Guatemala (fig. 2), and this, plus a reported discovery in southeastern Chiapas near the Guatemalan border, adds further interest in the possibilities of the Peten basin.

\section{RESERVOIRS}

The important reservoirs in the Mesozoic and lower Tertiary carbonate fields at Reforma and Campeche are in the dolomitized and intensely microfractured high-energy bank-edge (Tamabra) facies of Cretaceous and Paleocene age (figs. 5, 6, $12,13)$. Much of this facies is a brecciated reef-derived talus. Primary porosity is not necessarily high and is related to original pore spaces in reefal organisms and interparticle detritus. Secondary porosity is related to dolomitization, solution cavities, and intense brecciation caused by movement of underlying salt. This facies is projected to be present in the subsurface along the seaward side of the El Abra reef and back-reef bank facies 
around most of the Yucatan platform and to extend west from Reforma along the southwest flank of the Veracruz basin (Viniegra-O., 1981). However, according to some authors (Castillo, 1955; Benavides, 1960; Viniegra-O., 1971; Bishop, 1980), this facies probably was removed by erosion in the western part of the Isthmus Saline basin where all or part of the Cretaceous is thin or missing. It may be present in the subsurface near the southern edge of the basin and in subthrust position at depth adjacent to the Sierra Madre Oriental along the southwestern margin of the Veracruz basin (fig. 8).

The lower part of the Sierra Madre Limestone in southern Chiapas is dolomitized, and dolomite also is common in the upper part of the formation (Mora and others, 1975). Thick beds of crystalline dolomite and thick limestone breccias are reported in the lower part of the Cretaceous outcrop sequence in Guatemala (Hillbank Dolomite and other units) (Clemons and Burkart, 1971; Anderson and others, 1973; Bishop, 1980). These breccias were interpreted as possibly intraformational or collapse breccias rather than forereef breccias (Blount and Moore, 1969). Fractured dolomite beds interbedded with anhydrite in the Peten basin are the reservoirs in the Rubelsanto area oil fields.

Porous and fractured carbonate beds of reservoir quality are common in the Sierra Madre belt of southeastern Mexico and Guatemala and on the Yucatan Peninsula. However, throughout most of this tropical rain forest area, parts of the thick Cretaceous carbonate sequence are exposed and probably flushed by meteoric waters. In the subsurface of eastern Chiapas and Guatemala, however, carbonate units are interbedded with anhydrite, or a Tertiary cover is present. Flushing should be less effective here, and impermeable seals are also present for trapping petroleum.

Upper Jurassic (Oxfordian) bank carbonate beds were penetrated by several wells at Reforma and offshore Campeche, where oil-saturated reservoirs of dolomitized oolitic and bioclastic units are reported. This facies, as much as 500 to $1,000 \mathrm{~m}$ or more $(1,600$ to $>3,300 \mathrm{ft}$ ) thick (fig. 11$)$, is similar to the Limestone facies of the Smackover Formation of the U.S. Gulf Coast and the Zuloaga Limestone of northern Mexico. Its areal extent in southern Mexico and Guatemala is speculative, but it may underlie much of the area where the the Cretaceous El Abra-Tamabra bank margin and talus facies are present.
The organic-rich black shale and limestone source-rock facies of Late Jurassic (KimmeridgianTithonian) age in the Reforma and offshore Campeche areas may be present throughout much of the main salt area in the Gulf Coast basins and along the western border of the Yucatan platform. This facies was deposited under restricted basin conditions and thus also may have been deposited in other Mesozoic evaporite basins. A similar facies of the same age overlies a Jurassic evaporite sequence in other parts of the Gulf of Mexico province and may be present in much of the Jurassic salt area in southern Mexico and Guatemala.

Lower Cretaceous dark shale and shaly limestone beds also are probable source beds for oil in Cretaceous and Paleocene reservoirs (Viniegra-O., 1981; Bishop, 1980; Acevedo and Dautt, 1980). These beds are not as organically rich as those of the Upper Jurassic but, in places, may be of substantial thickness. Because of similarities in depositional history, the distribution of these beds should be similar to that of the Upper Jurassic organic-rich beds. Other potential source beds may include the Tamaulipas facies offshore from the main bank-edge belt, although these beds are not reported to have a significantly high organic content. Similar Upper Cretaceous deeper water beds may be present locally within the main bank carbonate complex and in the foredeep area north of the Sierra Madre del Sur in Guatemala.

\section{REGIONAL CAP ROCKS}

The Tertiary shale facies of the Reforma and Campeche areas is present everywhere north of the Sierra Madre Oriental and should extend around the periphery of the Yucatan platform, where these beds are probably mainly marls. On the Yucatan platform, Tertiary beds are primarily carbonate rocks and, except for some anhydrite beds, probably do not contain adequate cap rocks. Except for local areas of preservation, the Tertiary shale facies is absent in much of Chiapas, although it is somewhat more widespread but thinner in eastern Chiapas and Guatemala. Anhydrite beds, interbedded with carbonate beds in the Lower and "middle" Cretaceous sequence in Guatemala and much of Chiapas, should be efficient seals for the underlying reservoirs of folded carbonate or clastic beds. 
taceous in southeastern Chiapas and Guatemala

Almost all of the carbonate Mesozoic oil accumulations in the Reforma and Campeche shelf provinces have been found on complexly faulted salt structures. Originally, both areas may have been giant stratigraphic accumulations (Viniegra-O., 1981) that were remigrated and segmented by Laramide structural growth and subsequent episodes of salt movement. Thrust or reverse and normal fault traps are documented on many of the structures, and local stratigraphic traps also may be present within the structural complexes. At least 200 undrilled structures in the Tabasco and offshore Campeche areas with probable salt cores are reported. Fields in the Rubelsanto area of Guatemala also are on salt structures, but these appear to be less complex. Salt structures also may be present in much of the remaimder of the Peten basin, including the north basin where a significant discovery was recently announced (World Oil, 1981). The numerous broad domal or anticlinal structures mapped on the Yucatan Peninsula and to the north on the offshore Yucatan platform may be flushed by meteoric waters from the exposed carbonate sequence on the peninsula. Likewise, the complex of anticlinal and fault structures in the Sierra Madre de Chiapas have undergone massive flushing of the carbonate reservoirs because of exposure and lack of adequate stratigraphic seals.

\section{ANALOGS}

Facies analogs to the Mesozoic-Tertiary carbonate bank province of southern Mexico and Guatemala are found in most of the equivalent age carbonate complex surrounding the Gulf of Mexico basin. The processes of organic carbonate buildups, postdepositional history, dolomitization, karstification, and brecciation by salt movements have in varying degrees similarly affected this reservoir and source rock facies in many other productive areas, including the Tampico-Golden Lane, Sabinas basin, and U.S. Gulf Coast areas.

\section{PRE-OXFORDIAN MESOZOIC CLASTIC DEPOSITS}

Thick sandstone and conglomerate beds are present in outcrops of the Todos Santos (red bed) Formation in Chiapas and Guatemala. These beds are pre-Oxfordian Jurassic and probably Triassic in age and may be in part as young as Early Cre-
(Bishop, 1980; Vinson, 1962; Viniegra-O., 1971, 1981). In places, this section contains marine fossils, particularly in the upper part, and porous sandstones are present, although their distribution and reservoir character in the subsurface is relatively unknown because of lack of control. The facies apparently occurs throughout most of the region, having been reported in the subsurface as far north as offshore Campeche, Reforma, and the western part of the Isthmus Saline basin, as well as in wells on the Yucatan Peninsula. Much of the Todos Santos sequence is continental in origin and is unlikely to contain beds with sufficient organic material to serve as source rocks for petroleum. However, the upper, more marine part may contain more organic matter in places, particularly in the more basinal or graben-trough areas of the depositional province. The possibility of nonindigenous petroleum in these beds should be greater in structurally high areas where the underlying upper Paleozoic marine section may include source-rock beds, particularly in northern Guatemala and eastern Chiapas (Bishop, 1980). Evaporites, which are interbedded with or overlie the Todos Santos in most of Chiapas, Guatemala, the Gulf coastal plain, and the offshore Campeche areas, provide a regional seal for these beds.

\section{PALEzoIC Rocks}

Pre-Pennsylvanian sedimentary rocks are metamorphosed wherever observed and, except for the possibility of anomalous fracture reservoirs, are unlikely to contain hydrocarbons. However, a sequence of marine Pennsylvanian and Permian rocks 2,000 $\mathrm{m}$ or more ( $6,600 \mathrm{ft}$ ) thick in places is known from outcrop studies in southeastern Chiapas and Guatemala and probably is widespread in the subsurface of Chiapas and Guatemala (figs. 5, 7) (Bishop, 1980; Paine and Meyerhoff, 1970; Garcia, 1973; Lopez-Ramos, 1969; Anderson and others, 1973; Clemons and others, 1974). These beds are metamorphosed in places but may be unmetamorphosed in much of the subsurface. The lower part of the sequence consists of basal conglomerate, sandstone, and marine shale beds overlain by fossiliferous limestone and shale, some of which apparently have source-rock quality. Oil seeps are present in outcrops of these beds in Chiapas (Bishop, 1980). The section is essentially unexplored for petroleum 
and is deeply buried in much of southeastern Mexico and Guatemala but is considered to have good potential for hydrocarbons in Chiapas and parts of Guatemala (Garcia, 1973; Bishop, 1980). Regional cap rocks may not be present in the Paleozoic section, but the overlying Todos Santos clastic and evaporite beds should provide an adequate seal on structures.

Insufficient data are available for satisfactory analog comparisons with the upper Paleozoic section. However, this marine sequence was deposited in the Paleozoic geosyncline of Mexico, which is an extension of the Pedregosa and Delaware basin depositional province of southwestern United States and northern Mexico. There may be some similarities between the carbonate and clastic reservoir facies and potential source-rock facies of these two areas.

\section{GIANT FIELDS}

TERTIARY BASIN FIELDS

Acevedo and Dautt (1980) report five giant oil fields (more than $100 \mathrm{MMB}$ ) in the Tertiary Isthmus Saline basin and three giant gas fields (more than 0.6 Tcf) in the Macuspana basin (fig. 2). Cumulative production through 1980 in the larger Isthmus Saline basin fields is as follows: Cinco Presidentes (fig. 15) (227 million barrels of oil (MMBO)), El Plan (147 MMBO), Magallanes (126 MMBO), Orragio (119 MMBO), and Tonala'El Burro (95 MMBO). Production in these fields is from Tertiary sandstones, mainly the lower Miocene Encanto Formation, on complexly faulted diapiric salt domes. The largest Macuspana basin fields are Jose Colomo, Chilapilla (fig. 16), and Hormiguero, all of which produce from faulted anticlines that may be related to deep-seated salt structures. These fields produce gas and condensate from sandstone reservoirs in the middle Miocene Amate Formation. Specific data on the Cinco Presidentes and Jose Colomo-Chilapilla fields are summarized in table 2.

\section{REFORMA FIELDS}

By January 1981, 36 fields had been discovered in the Reforma area. Four of these (Sitio Grande, Cactus, A. J. Bermudez complex, and Iris Giraldas complex) are reported as giant or supergiant fields (Acevedo and Dautt, 1980). Production is from Cretaceous and Upper Jurassic microfrac- tured dolomite reservoirs on complexly faulted salt structures. The A. J. Bermudez complex is a combination of four fields discovered between 1973 and 1977, which with further development drilling, turned out to be part of a giant accumulation on a complexly faulted salt structure (fig. 18). Production is from microfractured Cretaceous and Upper Jurassic dolomite reservoirs with pay thickness as much as $1,200 \mathrm{~m}(4,000 \mathrm{ft})$. By mid1980 , the complex had produced more than $2 \mathrm{BB}$ of oil and more than 3 Tef of gas. Because the reservoirs are undersaturated, an intensive waterflood project was set up early in the history of the field, and in 1981 more than $1,000,000 \mathrm{bbl} / \mathrm{d}$ of water were being injected (World Oil, 1981). Detailed reservoir and production data for the main Reforma fields are summarized in table 2, and the general stratigraphic column of the area is shown in table 3.

\section{OFFSHORE CAMPECHE FIELDS}

By July 1980, production from the offshore Campeche fields was $784,000 \mathrm{bbl} / \mathrm{d}$ from 24 wells averaging more than $32,000 \mathrm{bbl} / \mathrm{d}$ each; in March 1981, production had increased to 1.3 million bbl/ d, mainly from the Cantarell complex. The Cantarell complex includes the Akal, Nohoch, and Chac fields, which make up a single supergiant accumulation (figs. 6, 19, 20, 21). Production is from Paleocene and Cretaceous microfractured and vuggy brecciated dolomite reservoirs with pay thicknesses as much as $1,000 \mathrm{~m}(3,300 \mathrm{ft})$ or more. Production rates of individual wells are extremely high because of the intense fracturing of the reservoir rock. The structure of the Cantarell complex is complicated by normal, reverse, and wrench faults related to movement of the salt. All or parts of the Cretaceous section are missing in places (Acevedo and Dautt, 1980). Another group of fields, the Abkatun-Kanaab-Taratunich-Ixtoc complex, is in the early stages of development but is predicted to be a second supergiant accumulation in this offshore area (Acevedo and Dautt, 1980).

Data pertinent to these two largest productive complexes are summarized in table 2 , and the general stratigraphic column of the area is shown on table 3.

\section{SUMMARY}

GENESIS OF THE PETROLEUM DEPOSITS

The sequence of geological events that resulted 
in the accumulation of major deposits of petroleum in southern Mexico can be summarized as follows:

1. Deposition of a sequence of upper Paleozoic marine clastic and fossiliferous carbonate beds $2,000 \mathrm{~m}$ or more $(>6,600 \mathrm{ft})$ thick in the Mexico geosyncline north of the Sierra Madre del Sur province.

2. Seafloor and continental-margin spreading around the border of the North American continent and development of a Triassic graben trough system. Deposition of Triassic and Lower Jurassic continental and marine red beds, conglomerates, and evaporite deposits occurred and eventually spread across most of the southeast Mexico-Guatemala area, but deposition was thickest in elongate fault-bounded troughs of the Early Triassic structural complex.

3. Deposition of a thick sequence of Middle and lower Upper Jurassic evaporite deposits with halite and gypsum interbedded with red beds, mostly in the vicinity of the main graben troughs inherited from the Triassic tensional structural event.

4. Late Jurassic (Oxfordian-Kimmeridgian) marine transgression and wide-spread deposition of marine carbonate and dark shaly beds within the entire Gulf of Mexico province. This event marked the early building of the bank carbonate complex in shallowwater marine areas around the Gulf of Mexico basin.

5. Latest Jurassic (Kimmeridgian-Tithonian) marine regression and deposition of organic-rich dark shale, silt, and argillaceous carbonate beds, primarily in trough areas where the main sequence of Jurassic evaporite deposits had previously been deposited.

6. Transgressive-regressive cyclic deposition of unusually thick platform and bank organic carbonate and evaporite beds of the major Cretaceous transgressive cycle. In the main platform areas of the Gulf of Mexico province, the El Abra bank and reef-carbonate and backreef evaporite beds were deposited, and deeper water dark calcareous shale and argillaceous carbonate beds (Tamaulipas facies) accumulated in the main Gulf of Mexico basin. Along the platform borders and at places within the plat- form, the forereef or bank-edge talus deposits (Tamabra facies) formed, mainly during low sea-level (regressive) stages of the cycle, with a particularly important and widespread development of this facies at the close of the "middle" Cretaceous (Aptian-Albian). Solution, karstification, and early dolomitization of the bank carbonate sequence probably occurred with regional emergence of the carbonate complex, particularly around the platform borders where seepage-reflux and basinal dolomitization processes were effective.

7. Laramide tectonic movements, beginning sometime during the Late Cretaceous, with north- and northeast-directed compressive stresses, causing uplift of the Sierra Madre del Sur, development of an adjacent foredeep trough immediately to the north, and imbricate folding and thrust faulting in the Sierra Madre Oriental and Sierra Madre de Chiapas. As interpreted by Viniegra-0. (1971, 1981) and Lopez-Ramos (1979), regional left-lateral transcurrent normal faulting occurred in association with the compressive Laramide stresses, and parts of the thick carbonate-bank complex were displaced toward the west or northwest, particularly in the Veracruz, Reforma shelf, and Campeche shelf areas, and perhaps in other parts of the platform.

8. Laramide structural activity accompanied by increased clastic influx into the basin areas. Thick deposits of shallow- and deepwater Upper Cretaceous and lower Tertiary marine and nearshore continental beds were deposited along the Cretaceous platform carbonate front and adjacent deepwater areas of the Gulf of Mexico (Veracruz, Isthmus Saline, Macuspana, and Comalcalco basins). Deposition of these beds on the Reforma shelf, Campeche shelf, and the Veracruz thrust front caused further sagging of these offset blocks and deeply buried the Mesozoic sequences within the main coastal basin province. Vertical faulting along the borders of the blocks may have begun at this time, initiating the delineation of the Villahermosa horst, as well as the Macuspana, Comalcalco, and other basin-border faults. 
9. At some time during the early Tertiary, maturation of the Upper Jurassic and Lower Cretaceous organic-rich argillaceous beds due to burial depths. Also at this time or perhaps earlier, burial depths and post"middle" Cretaceous sediment thickness differences were sufficient to cause extensive vertical salt movement, although salt movement may have begun earlier, perhaps in part stimulated by Laramide compressive stresses. Petroleum generation and migration probably began at this time, with early migration directed out of the more deeply buried basinal areas and toward the shelf areas such as the Reforma shelf, the Campeche shelf, and the carbonate-bank border. At the same time, salt movement would have been directed toward areas of shallower burial within the salt province (Reforma shelf, Campeche shelf, western Isthmus Saline basin area near the Salina Cruz fault and others). Brecciation of overlying dolomitized carbonate beds also occurred, enhancing the movement of generated petroleum into the salt-uplift areas.

10. Deposition of thick offshore and nearshore marine clastic rocks in the coastal basin province, resulting in further vertical salt movement and continuation of Mesozoic source-bed maturation, at least through most of the Miocene. Intensified microfracturing of carbonate reservoirs and redistribution of earlier petroleum deposits in the Mesozoic reservoirs continued until the present-day accumulations were essentially formed. During this time, deep burial of much of the lower and middle Tertiary marine sedimentary rocks reached the thermal-maturity stage. Gas, condensate, and some oil were generated and migrated into adjacent sandstone beds of the lower and middle Miocene nearshore sand and carbonaceous shale reservoir-source rock complex. These petroleum accumulations were further redistributed during the final phases of salt-structure growth. At some time during the middle Tertiary, as salt movement reached a maximum, salt piercement structures probably began to form in the western part of the Isthmus Saline basin, resulting in upward migration into Miocene sandstone reservoirs of Mesozoic oil from earlier formed fractured Mesozoic reservoirs on the main salt structures.

11. Continued burial of salt structures and of earlier formed Laramide structures in the coastal plain province during latest Tertiary time, resulting perhaps in some minor redistribution of previously formed petroleum deposits.

\section{INFORMATION SUMMARY}

Geologic province:

Mesozoic-Tertiary continental margin basin

Area:

$325,000 \mathrm{mi}^{2}$

Volume of sediment:

$1,100,000 \mathrm{mi}^{3}$

Prospective intervals:

A. Upper Paleozoic carbonate-clastic beds

B. Pre-Oxfordian Jurassic clastic beds

C. Oxfordian-Tithonian (Jurassic) carbonate-clastic beds

D. Cretaceous carbonate facies

E. Paleocene-Eocene carbonate facies

F. Lower and upper Tertiary Paleocene-Miocene clastic beds

\section{Source beds:}

A. Upper Jurassic dark shale and carbonate beds

B. Lower and "middle" Cretaceous dark shale and carbonate beds

C. Tertiary marine shales

Prospective trap types:

A. Reef, forereef talus, back-reef carbonates, porosity-permeability variations

B. Marine sandstones-lense, channel, bar, and porositypermeability variations

C. Salt swells and domes, anticlines, fault traps

D. Combination traps

Principal plays:

A. Structure to immediate northwest and southwest of Cantarell, including possible horst block high in the depression between Cantarell and Reforma

B. Undrilled structures in Reforma area

C. Possible reef area in Guatemala

D. North basin area of Guatemala where Tertiary cover is present

E. Southeastern Chiapas-western Guatemala where Tertiary cover is present

F. Buried thrust play in Veracruz basin

G. Stratigraphic play seaward and against the Yucatan escarpment

H. Sediment troughs in offshore salt structure area

I. Deep Paleozoic gas in Chiapas and Guatemala

Exploration stage of province:

A. Intermediate in Tertiary basins

B. Early in deeper onshore Mesozoic and offshore provinces Number of fields:

About 125 oil or oil and gas; about 30 to 35 gas fields 
Average depth of undiscovered resources:

A. Oil $-4,500$ to $5,500 \mathrm{~m}$

B. Gas $-5,000$ to $6,000 \mathrm{~m}$

Analogs:

Tampico basin, Mexico; Persian Gulf; Permian basin, U.S.; western Gulf basin, U.S.; Arctic slope, U.S.

\section{RESOURCE ASSESSMENT}

\section{PROCEDURES}

The resource assessment of this region was conducted by the Resource Appraisal Group (RAG) of the USGS, Branch of Oil and Gas Resources, following the standard procedures developed since 1974 for analysis of domestic petroleum resources. The technique, briefly, requires study of a given area paying particular attention to the geologic factors controlling the occurrence, quality, and quantity of the petroleum resource. Standardization of critical elements of the investigations is achieved by the preparation of data forms for each basin, which include specific volumetric, areal, and rock-quality measurements, as well as the determination of basin analogs for comparison purposes. In addition, finding-rate histories and projections are constructed where possible. From these data and analyses, various analytical techniques are used to calculate a set of resource numbers. Not considered in this assessment are resources of heavy oil deposits, tar deposits, and oil shales, as well as gas in low permeability reservoirs, in occlusions in coal, in geopressured shales and brines, and in natural gas hydrates.

The assessment process itself is subjective; the results of the geological investigation and of the resource calculations are presented to a team of assessment specialists who make their personal estimates, conditional upon recoverable resources being present. Initial assessments are made for each of the assessed provinces as follows:

(1) A low resource estimate corresponding to a 95-percent probability of more than that amount; this estimate is the 95th fractile $\left(\mathrm{F}_{\mathbf{9 5}}\right)$.

(2) A high resource estimate corresponding to a 5-percent probability of more than that amount; this estimate is the 5th fractile $\left(\mathrm{F}_{5}\right)$.

(3) A modal ("most likely") estimate of the quantity of resource associated with the greatest likelihood of occurrence.
The individual estimates are then posted and averaged, and the results are debated from the perspective of the personal experiences of the individual assessors; a second and third iteration of the procedure may follow depending on consensus. If no commercial oil has been heretofore discovered in the basin, then a marginal probability is subjectively assessed that reflects the probability that any commercial oil will ever be discovered. The results of the final estimates are averaged, and those numbers are computer processed by using probabilistic methodology (Crovelli, 1981) to show graphically the resource values associated with a full range of probabilities and to determine the 95th fractile, the 5th fractile, and the mean, as well as other statistical parameters.

\section{ASSESSMENT}

The locations of the southeastern Mexico, northern Guatemala, and Belize basins are shown in figure 1. Unconditional estimates by the USGS of oil and gas resources in these basins are shown in table 4 and in figures 22 and 23. Data supporting these estimates are supplied in table 5.

\section{COMMENTS}

The Reforma-Campeche reservoirs are salt assisted and apparently require assistance for fracturing.

The production between Reforma and Campeche is limited by a deep trough that places potential source rocks below oil or gas generation levels. An uplifted structural block is, however, inferred in the area, which is part of the exploration potential.

North of the offshore Campeche fields, production is limited by (1) loss of salt assist, (2) loss of seal (Tertiary deltaic and offshore marine sands and shales derived from the south), and (3) possible flushing from the Yucatan high to CretaceousJurassic outcrops on the seafloor.

The Ixchel well north of offshore Campeche, earlier reported as a discovery and later reported not to have been drilled, clouds the assessment of the north Yucatan platform area. This assessment assumes the well does not exist.

Most of northern Guatemala appears to be in a back-reef facies and probably not in a position to contain major resources. Inferences of reef development, however, lend some encouragement. 


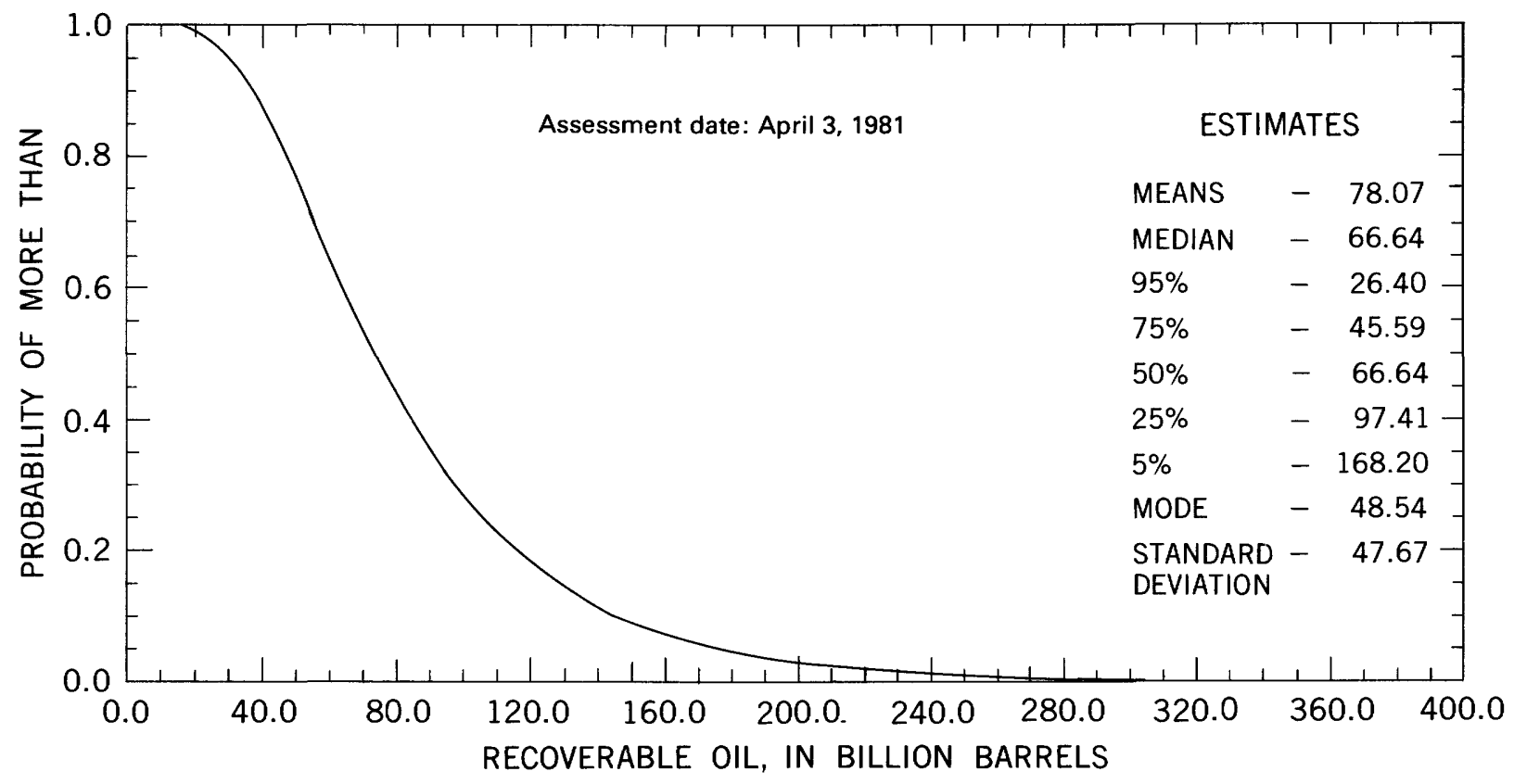

FIGURE 22.- Unconditional estimates of recoverable oil in southeast Mexico, northern Guatemala, and Belize (assessment date, April 3, 1981).

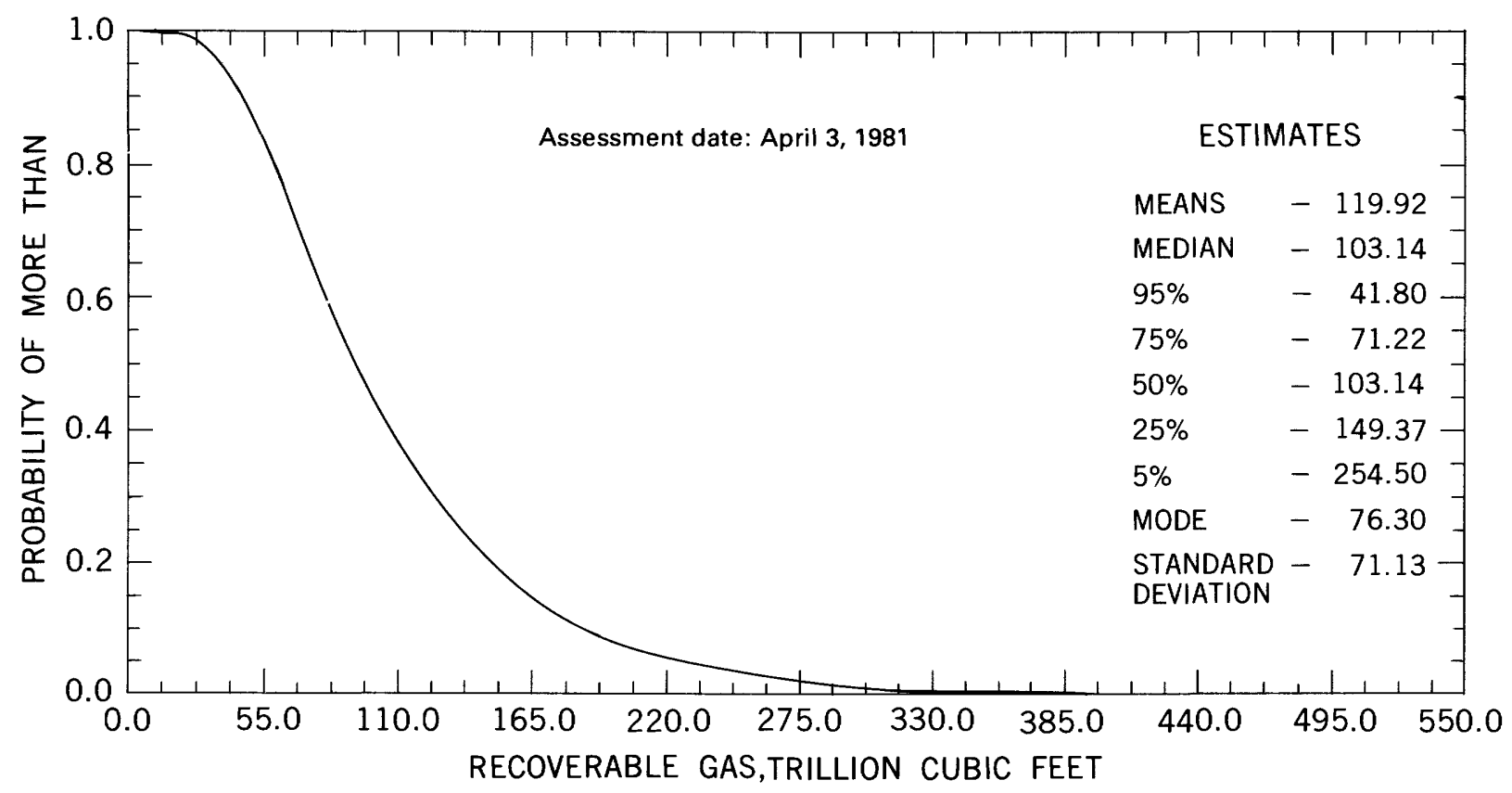

FigURE 23.-Unconditional estimates of recoverable total gas in southeast Mexico, northern Guatemala, and Belize (assessment date April 3, 1981). 
A buried overthrust play in Veracruz basin is deep but promising.

Oil occurrence and entrapment in the area is a combination of many factors, each of which has unique areal limits; therefore, it is not reasonable to count structures and assume a percentage of discoveries.
TABLE 4.-Assessment of conventionally recoverable petroleum resources of southeastern Mexico, northern Guatemala, and Belize

[Unconditional resource assessment by USGS as of April 3, 1981; see figures $2 \overline{2}$ and 23 also]

\begin{tabular}{|c|c|c|}
\hline \multicolumn{3}{|c|}{ Crude oil } \\
\hline \multicolumn{2}{|c|}{ Probability of occurrence, in percent } & $\begin{array}{l}\text { Billions of barrels } \\
\text { (BB) }\end{array}$ \\
\hline $95-$ & & 26 \\
\hline 5 -ーーーーーーーーー & & 168 \\
\hline Mean - & $-\infty-$ & 78 \\
\hline \multicolumn{3}{|c|}{ Natural gas } \\
\hline $\begin{array}{l}\text { Probability of occurrence, } \\
\text { in percent }\end{array}$ & $\begin{array}{c}\text { Trillions of cubic feet } \\
\text { (Tcf) }\end{array}$ & $\begin{array}{l}\text { Billions of barrels of oil } \\
\text { equivalent (BBOE) } \\
\text { at } 6,000 \mathrm{ft}^{3} / \mathrm{bbl}^{1}\end{array}$ \\
\hline 95 ーேーーーーーーーーーーー & 42 & 7 \\
\hline 5ーーーーーーーーーーー & 254 & 42 \\
\hline Mean - - - - - & 120 & 20 \\
\hline
\end{tabular}

'Pemex commonly reports barrels of oil equivalent at $5,000 \mathrm{ft}^{2} / \mathrm{bbl}$, but the $6,000: 1$ conversion is used here for comparability with other assessments made by USGS.

TABLE 5.-Supplementary and comparative data supporting the resource assessment for southeastern Mexico, northern Guatemala, and Belize ${ }^{1}$

\begin{tabular}{|c|c|c|c|}
\hline \multirow[b]{2}{*}{ Cumulative production to $1 / 1 / 80$} & $\begin{array}{c}\text { Crude oil } \\
\text { Billions of barrels (BB) }\end{array}$ & \multicolumn{2}{|c|}{$\begin{array}{c}\text { Natural gas } \\
\text { Trillion cubic feet (Tct }\end{array}$} \\
\hline & & & \\
\hline & 5 & & 8 \\
\hline \multicolumn{4}{|l|}{ Identified reserves to $1 / 1 / 80^{\circ}$} \\
\hline \multirow{4}{*}{$\begin{array}{l}\text { Demonstrated --C_- } \\
\text { Inferred - }\end{array}$} & 27 & & 45 \\
\hline & 26 & & 20 \\
\hline & 53 & & 65 \\
\hline & & BBOE & 11 \\
\hline \multicolumn{4}{|c|}{ Original recoverable resources (ultimate) of assessment area } \\
\hline Cumulative -C & 5 & & 8 \\
\hline 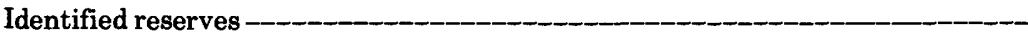 & $56^{3}$ & & 65 \\
\hline Undiscovered resources (mean) & 78 & & $\underline{120}$ \\
\hline & $\overline{139}$ & & 193 \\
\hline Total BBOE-_____- & 171 & BBOE & 32 \\
\hline
\end{tabular}

Original recoverable resources (ultimate) BBOE:

Cumulative production/oil

Cumulative production/gas

Identified reserves/oil

Identified reserves/liquid

Identified reserves/gas

Mean undiscovered resources/gas

24.0

Total BBOE

$\frac{24.0}{177.5}$

${ }^{1}$ Cumulative production and reserves are composited estimates from various sources.

'Follows terminology outlined in USGS Circular 831. Demonstrated is equivalent to API Proved and Indicated Additional. Inferred represents anticipated field growth in existing fields.

'Included 3 BB natural-gas liquids. 


\section{SELECTED REFERENCES}

Acevedo, J. S., 1979, Petroleum geology of Campeche offshore area, southeastern Mexico (abs): American Association of Petroleum Geologists Bulletin, v. 63, p. 697.

Acevedo, J. S., and Dautt, O. M., 1980, Giant fields in the southeast of Mexico: Transactions Gulf Coast Association of Geological Societies, v. 30, p. 1-31.

Alvarez, M., Jr., 1949, Tectonics of Mexico: American Association of Petroleum Geologists Bulletin, v. 33, p. 1319-1335.

Anderson, T. H., Burkart, B., and Clemons, R. E., 1973, Geology of the western Altos Cuchumatanes, northwestern Guatemala: Geological Society of America Bulletin, v. 84, p. $805-826$.

Beebe, B. W., 1968, The occurrence of natural gas in Mexico: American Association of Petroleum Geologists Memoir 9 , p. 209-232.

Benavides, G. L., 1960, Notas sobre la geologiade la Cuenca Salina del Istmio (Notes on the Geology of the Isthmus Saline Basin): Soc. Mex. Mec. Suelos, v. 5, p. 98-101.

Bishop, W. F., 1980, Petroleum geology of northern Central America: Journal of Petroleum Geology, v. 3, p. 3-59.

Blount, D. N., and Moore, C. H., Jr., 1969, Depositional and nondepositional carbonate breccias, Chiantla Quadrangle, Guatemala: Geological Society of America Bulletin, v. 80, p. $429-442$.

Bryant, W. R., Meyerhoff, A. A., and Brown, N. K., Jr., 1969, Escarpments, reef trends, and diapiric structures, eastern Gulf of Mexico: American Association of Petroleum Geologists Bulletin, v. 53, p. 2506-2542.

Burkart, B., Clemons, R. E., and Crane, D. C., 1973, Mesozoic and Cenozoic stratigraphy of southeastern Guatemala: American Association of Petroleum Geologists Bulletin, v. 57, p. 63-73.

Castillo, T. C., 1955, Bosquejo estratigrafico de la cuenca Salina del Istmo de Tehuantepec (Stratigraphical outline of the Isthmus Saline basin of Tehuantepec): Boletin de la Asociacion Mexicana de Geologos Petroleros, v. 7, p. 173212.

Castillon, M., and Larios, J. P., 1963, Salt deposits of the Isthmus of Tehuantepec, in Symposium on Salt: Northern Ohio Geological Society, p. 263-280.

Chubb, L. J., 1959, Upper Cretaceous of central Chiapas, Mexico: American Association of Petroleum Geologists Bulletin, v. 43 , p. $725-755$.

Clemons, R. E., Anderson, T. H., Bohnenberger, O. H., and Burkart, B., 1974, Stratigraphic nomenclature of recognized Paleozoic and Mesozoic rocks of western Guatemala: American Association of Petroleum Geologists Bulletin, v. 58, p. $313-320$.

Clemons, R. E., and Burkart, B., 1971, Stratigraphy of northwestern Guatemala: Boletin de la Asociacion Mexicana de Geologos Petroleros, v. 32, p. 143-158.

Contreras, V. H., and Castillon, M. B., 1968, Morphology and origin of salt domes of Isthmus of Tehuantepec: American Association of Petroleum Geologists Memoir 8, p. 244-260.

Crovelli, R. A., 1981, Probabilistic methodology for oil and gas resource appraisal, U. S. Geological Survey Open-File Report 81-1151.

Cruz-Helu, P., Verdugo, V. R., and Barcenas, P. R., 1977, Origin and distribution of Tertiary conglomerates, Veracruz basin, Mexico: American Association of Petroleum Geologists Bulletin, v. 61, p. 207-226.
Delgado, O. R., and Loreto, E. C., 1975, Reforma's Cretaceous reservoirs, an engineering challenge: Petroleum Engineer, v. 47 , p. $55-56$.

Dengo, G., 1969, Problems of tectonic relations between Central America and the Caribbean: Gulf Coast Association of Geological Societies, no. 19, p. 311-320.

Dengo, G., and Bohnenberger, O. H., 1969, Structural development of northern Central America: American Association of Petroleum Geologists Memoir 11, p. 203-220.

Fisher, W. L., 1979, Oil and gas in Mexico: Texas Business Review, v. 53, p. $29-34$.

Frost, S. H., and Langenheim, R. L., Jr., 1974, Cenozoic reef biofacies: Northern Illinois University Press, 373 p.

Garcia, R. H., 1973, Palogeografia del Paleozoico de Chiapas, Mexico (Paleozoic Paleogeography of Chiapas, Mexico), Boletin de la Asociacion Mexicana de Geologos Petroleros, v. 25 , p. $79-113$.

Garcia, M. N., 1978, Correlacion de registros geofisicos de pozos perforados en el area Tabasco Chiapas y la platforma continental de Campeche y Yucatan (Correlation of geophysical logs of wells drilled in the Tabasco-Chiapas area and the continental platform of Campeche and Yucatan): Energeticos Boletin Inform. del Sector Energetico, Ano 2, p. 1-24.

Grossling, B. F., 1979, Brief on Reforma-Campeche's (Mexico) petroleum potential: U.S. Geological Survey Open-File Report 79-237, 52 p.

Guttierez-Gil, R., 1960, Tehuantepec salt domes may mark potential oil territory for Mexico: Oil and Gas Journal, v. 58, no. 8, p. 150-160.

Gutierrez-Gil, R., and Thompson, M. L., 1956, Geologia del Mesozoico y estratigrafia permica del Estado de Chiapas (Geology of the Mesozoic and Permian stratigraphy of the State of Chiapas): 20th Geological Congress, Mexico, Excursion C-15, 82 p.

Guzman, E. J., and de Cserna, Z., 1963, Tectonic history of Mexico: American Association of Petroleum Geologists, Memoir 2, p. 113- 129.

Guzman, E. J., Suarez, R., and Lopez-Ramos, E., 1955, Outline of the petroleum geology of Mexico: Conference on Latin-American Geology, University of Texas, Austin, p. 1-30.

Hernandez, G. R, 1973, Paleogeografia del Paleozoico de Chiapas, Mexico (Paleozoic Paleogeography of Chiapas, Mexico): Boletin de la Asociacion Mexicana de Geologos Petroleros, v. 25, p. 78-113.

Herrera, C. G., 1973, Geological and geohydrological studies for Angostura Dam, Chiapas, Mexico: Geological Society of America Bulletin, v. 84, p. 1733-1742.

Ives, G., 1975, Development of Reforma area oil fields: Petroleum Engineer, v. 47, p. 49-54.

Ladd, J. W., Buffer, R. T., Watkins, J. S., and Worzel, J. L., 1976, Seismic stratigraphy and geologic history of deep western Gulf of Mexico (abs.): American Association of Petroleum Geologists Bulletin, v. 60, p. 690.

Leigh, R. A., Buis, O. J., and Hall, W. K., 1976, Exploracion petrolera en Guatemala (Petroleum exploration in Guatemala): Third Congress Latinoam. Geol.

Lloyd, J. J., and Dengo, G., 1960, Petroleum possibilities of the Peten basin, Guatemala (abs.): in Program Bulletin, Annual Meeting, American Association of Petroleum Geologists, Atlantic City, April 25-28, 1960.

Lopez-Ramos, E., 1969, Marine Paleozoic rocks of Mexico: 
American Association of Petroleum Geologists Bulletin, v. 53, p. 2399-2417.

1973, Estudio geologico de la peninsula de Yucatan (Geologic study of the Yucatan Peninsula): Boletin de la Mexicana de Geologos Petroleros, v. 25, p. 23-75.

1975, Geological summary of the Yucatan Peninsula, in The Ocean Basins and Margins, the Gulf of Mexico and the Caribbean: Plenum Press, New York, p. 257-282.

1979, Geologia de Mexico (Geology of Mexico), 2d Edition, v. III: Mexico, D. F., 454 p. [Published by the author.]

Madrigal, U. L., 1974, Descubrimiento de yacimientos petroliferos en rocas carbonatadas del Cretacico en el suresta de Mexico (Discovery of petroleum deposits in Cretaceous carbonate rocks in southeast Mexico): Boletin de la Asociacion Mexicana de Geofisicos de Exploracion, v. 15, no. 3, p. 95-114.

Martin, R. G., 1980, Distribution of salt structures in the Gulf of Mexico: U.S. Geological Survey Miscellaneous Field Studies Map MF-1213, map and descriptive text.

Meyerhoff, A. A., and Morris, A. E. L., 1977, Central American petroleum centered mostly in Mexico: Oil and Gas Journal, Oct. 17, p. 104-109.

Mora, J. C., Schlaepfer, C. J., and Rodriguez, E. M., 1975, Estratigrafia y microfacies del Mesozoico de la Sierra Madre del Sur, Chiapas (Mesozoic stratigraphy and microfacies of the Sierra Madre del Sur, Chiapas): Boletin de la Asociacion Mexicana de Geologos Petroleros, v. 27, p. 1103.

Mossman, R. W., and Viniegra-O. F., 1976, Complex fault structures in Veracruz province of Mexico: American Association of Petroleum Geologists Bulletin, v. 60, p. 379388.

Nehring, R., 1979, Reserves resources and production possibilities, Mexico: R-2510-DOE, Rand Corporation, 56 p.

Oil and Gas Journal, 1978, Massive waterflood set for Reforma: v. 76, June 5, p. 96-102.

Paine, W. R., and Meyerhoff, A. A., 1970, Gulf of Mexico basin: interactions among tectonics, sedimentation, and hydrocarbon accumulation: Gulf Coast Association of Geological Societies, no. 20 , p. $5-44$.

Petroconsultants S.A., International oil and gas records on Mexico, Geneva, Switzerland.

Richards, H. G., 1963, Stratigraphy of earliest Mesozoic sediments in southeastern Mexico and western Guatemala: American Association of Petroleum Geologists Bulletin, v. 47, p. $1861-1870$.

Ronfeldt, D., Nehring, R., and Gandera, A., 1980, Mexico's petroleum and U.S. Policy: Implications for the 1980's: R2510-DOE, Rand Corporation, 97 p.
Salas, G. P., 1967, Petroleo and azufre del sudeste de Mexico (Petroleum and sulphur of southeast Mexico): Boletin de la Asociacion Mexicana de Geologos Petroleros, v. 19, p. 9 32.

Salas, G. P., and Lopez-Ramos, E., 1951, Geologia y tectonica de las region de Macuspana, Tabasco, y parte norte Chiapas (Geology and tectonics of the Macuspana, Tabasco and north part of Chiapas region): Boletin de la Asociacion Mexicana de Geologos Petroleros, v. 3, p. 3-56.

Santiago, A. J., 1962, Estructuras de las porcion occidental del tente de la Sierra Madre de Chiapas (Structures of the western portion of the Sierra Madre of Chiapas): Boletin de la Asociacion Mexicana de Geologos Petroleros, v. 14, p. 111-136.

Vargas, A. F., 1978, A paleosedimentary study of Reforma area: Petroleo International, v. 36, p. 44-48.

Viniegra-O, F., 1965, Geologia del Macizo de Tezuitlan y la cuenca Cenozoica de Veracruz (Geology of the Tezuitlan massif and the Cenozoic basin of Veracruz): Boletin de la Asociacion Mexicana de Geologos Petroleros, v. 17, p. 101-163.

1970, Golden Lane fields, Veracruz, Mexico: American Association of Petroleum Geologists Memoir 14, p. 305325.

1971, Age and evolution of salt basins of southeastern Mexico: American Association of Petroleum Geologists Bulletin, v. 55, p. 478-494.

-1975a, La exploracion petrolera en Mexico de 1938 a la epoca actual (Petroleum exploration in Mexico from 1938 to the present): Boletin de la Asociacion Mexicana de Geologos Petroleros, v. 26, p. 425-456.

$-1975 \mathrm{~b}$, New oil discoveries in southeastern Mexico: American Association of Petroleum Geologists Bulletin, v. 59, p. 1277-1278, 1305-1307.

1981, Great carbonate bank of Yucatan, southern Mexico: Journal of Petroleum Geology, v. 3, p. 247-278.

Vinson, G. L., 1962, Upper Cretaceous and Tertiary stratigraphy of Guatemala: American Association of Petroleum Geologists Bulletin, v. 46, p. 425-456.

Watkins, J. S., Ladd, J. W., Shaub, E. S., Buffler, R. T., and Worzel, J. L., 1976, Seismic section WG-3 Tamaulipas shelf to Campeche scarp, Gulf of Mexico: American Association of Petroleum Geologists Seismic Section, no. 1, 6 p.

Watt, T., and Matheny, S. L., Jr., 1979, Pemex driving hard towards ambitious six-year plan goals: Oil and Gas Journal, v. 77, Aug. 20, p. 73-81.

Wilson, H. H., 1974, Cretaceous sedimentation and orogeny in nuclear Central America: American Association of Petroleum Geologists Bulletin, v. 58, p. 1348-1396.

World Oil, 1981, International outlook issue (Mexico and Guatemala): v. 193, no. 3, p. 89-109. 